\title{
Review Article \\ Pollution Status of Pakistan: A Retrospective Review on Heavy Metal Contamination of Water, Soil, and Vegetables
}

\author{
Amir Waseem, ${ }^{1}$ Jahanzaib Arshad, ${ }^{1}$ Farhat Iqbal, ${ }^{2}$ Ashif Sajjad, \\ Zahid Mehmood, ${ }^{3}$ and Ghulam Murtaza ${ }^{4}$ \\ ${ }^{1}$ Department of Chemistry, Quaid-i-Azam University, Islamabad 45320, Pakistan \\ ${ }^{2}$ Department of Statistics, University of Balochistan, Quetta 87300, Pakistan \\ ${ }^{3}$ Institute of Biochemistry, University of Balochistan, Quetta 87300, Pakistan \\ ${ }^{4}$ COMSATS Institute of Information Technology, Abbottabad 22060, Pakistan
}

Correspondence should be addressed to Amir Waseem; waseemq2000@hotmail.com

Received 28 February 2014; Revised 22 April 2014; Accepted 26 July 2014; Published 3 September 2014

Academic Editor: Jochen Bundschuh

Copyright (C) 2014 Amir Waseem et al. This is an open access article distributed under the Creative Commons Attribution License, which permits unrestricted use, distribution, and reproduction in any medium, provided the original work is properly cited.

\begin{abstract}
Trace heavy metals, such as arsenic, cadmium, lead, chromium, nickel, and mercury, are important environmental pollutants, particularly in areas with high anthropogenic pressure. In addition to these metals, copper, manganese, iron, and zinc are also important trace micronutrients. The presence of trace heavy metals in the atmosphere, soil, and water can cause serious problems to all organisms, and the ubiquitous bioavailability of these heavy metal can result in bioaccumulation in the food chain which especially can be highly dangerous to human health. This study reviews the heavy metal contamination in several areas of Pakistan over the past few years, particularly to assess the heavy metal contamination in water (ground water, surface water, and waste water), soil, sediments, particulate matter, and vegetables. The listed contaminations affect the drinking water quality, ecological environment, and food chain. Moreover, the toxicity induced by contaminated water, soil, and vegetables poses serious threat to human health.
\end{abstract}

\section{Introduction}

Those elements required in low quantity by living beings have been identified in the literature as microelements, trace elements, or micronutrients. These elements are necessary for living beings to continue life, but only in minor amount (e.g., vitamins and minerals). Specific nourishing demands of a living body are fulfilled through a combination of all types of macro- and micronutrients [1]. Trace element plays an important role in chemical, biological, biochemical, metabolic, catabolic, and enzymatic reactions in the living cells of plants, animals, and human beings. These elements appear in man and in food and in various environmental compartments in a broad concentration range from natural ultratrace levels at the ppt level and sometimes even below to the often increased due to anthropogenic pollution ppm level $[1,2]$. Some of the heavy metals are considered to be xenobiotics because these have no beneficial role in body functioning and are even very harmful in minor concentrations. Cadmium, beryllium, aluminum, uranium, mercury, lead, bismuth, barium, antimony, arsenic, and so forth are included in toxic metals. Higher levels of these metal ions are highly toxic to animals including humans and plants, and their solubility in water is considered to be one of the major environmental issues [3-5]. Environmental challenges of Pakistan are primarily associated with an imbalanced economic and social development in recent decades. All major cities of Pakistan face haphazard, unplanned expansion due to a shift of population from rural to urban areas which worsen the situation to cope up with this challenge. Since the municipal authorities or other utility service providers have limited resources, haphazard urban congestion is the prime reason for deterioration of natural resources (air, water, and soil quality). Access to clean drinking water is limited in developing countries and people may, therefore, consume contaminated water $[6,7]$. In Azad Jammu and Kashmir 
(AJ\&K), more than $80 \%$ of all illnesses have been attributed to the consumption of poor quality water [8]. It is estimated that water related diseases cause an annual national income loss of Rs. 25-58 billion and over 250,000 children in Pakistan die every year due to diarrheal diseases alone and $20-40 \%$ of the hospital beds in Pakistan are occupied by patients suffering from water-related diseases, which are responsible for onethird of all deaths [6, 7]. Only 25.61\% (rural 23.5\% and 30\% urban) of the population in Pakistan have access to safe and drinkable water [7].

Ground water is contributing about one-third in total water resources of Pakistan and is a sole source of water supplies in major municipalities [6, 9]. In Pakistan, main contributors to the surface and ground water pollution are the byproducts of various industries such as textile, metal, dying chemicals, fertilizers, pesticides, cement, petrochemical, energy and power, leather, sugar processing, construction, steel, engineering, food processing, mining, and others [7]. The discharge of industrial effluents, municipal sewage, farm, and urban wastes carried by drains and canals to rivers worsens and broadens water pollution $[10,11]$.

Sediment analyses play a crucial role in assessing the degree of heavy metal pollution and the resulting health risk associated with the food chain [12]. Coastal areas accommodate well over $60 \%$ of Karachi city (Pakistan) industries, including more than 6000 different industrial units such as chemical industries, textiles, pharmaceuticals, metal industries, oil refineries, petrochemical industries, and tanneries [13]. Huge quantities of industrial effluents and domestic sewage discharges, amounting to more than 300 million gallons per day, are directly discharged in the coastal areas via the Lyari and Malir Rivers (Karachi) and many open drains [14]. This, coupled with ever increasing population pressure, urbanization, and industrialization of the coastal areas, not only contributes to huge quantities of effluent discharges but also is of extreme importance as most are unregulated and untreated (less than 20\%). Consequently, the coastal marine environment is feared to be exposed to considerable pressure by metal contamination [15]. Disposal of sewage water and industrial wastes is a great problem. Often it is drained to the agricultural lands where it is used for growing crops including vegetables [16, 17]. Wastewater irrigation poses several threats to the environment through contamination by heavy metals. It also poses a number of potential risks to human health via the consumption of or exposure to pathogenic microorganisms and heavy metals [18].

\section{Pollution Status of Heavy Metal in Pakistan}

The environmental and human health effects of heavy metals depend on the mobility of each metal through environmental compartments and the pathways by which metals reach humans and the environment. The pollution status of heavy metals in Pakistan is of great concern and is reflected by the number of studies and accommodated in the form of Tables 1-3, along with maps showing some regions of interest (Figures 1-4). The following paragraph illustrates the current status of heavy metal pollution in different sources like water, soil, sediments, particulate matter, and vegetables.

2.1. Arsenic. Arsenic (As) is a toxic element and remains a significant human health concern as As and its compounds (inorganic) are carcinogenic to humans and are classified as Group 1, whereas organic As compounds such as mono- and dimethylarsinic acids are possibly carcinogenic to humans and are classified as Group 2B by International Agency for Research on Cancer [98]. Arsenic exposure causes a markedly elevated risk for developing a number of cancers, most notably skin cancer and cancers of the liver, lung, bladder, and possibly the kidney and colon $[99,100]$. During the 1990s, naturally occurring As was found to be widespread in groundwater in the USA, Argentina, Taiwan, China, Hungary, Vietnam, and the Ganges Plain [101]. The World Health Organization provisional guideline value for As concentration in drinking water is $10 \mu \mathrm{g} / \mathrm{L}$; similarly, various regulatory authorities or countries like USA or EU set guideline values for As due to the growing concern about this poisonous carcinogen andhave raised awareness of the dangers of As in drinking water [20]. Similarly in different areas of Pakistan we are facing the As related severe public health problems as they are present in other neighboring countries and in USA [102-104]. Arsenic concentration was found high in surface and groundwater in Pakistan mainly in two provinces, that is, Punjab and Sindh. Water resources (3\% and 16\%) having As contamination level of over $50 \mu \mathrm{g} / \mathrm{L}$ are reported in Punjab and Sindh, respectively, while $20 \%$ and $36 \%$ of water resources of Punjab and Sindh are contaminated with arsenic above $10 \mu \mathrm{g} / \mathrm{L}[105,106]$. The Pakistan Council for Research and Water Resources (PCRWR) and UNICEF have undertaken the assessment of drinking water quality since 1999 following the As crisis in Pakistan and other neighboring countries [9]. Consequently, the presence of As contaminated ground waters $10-200 \mu \mathrm{g} / \mathrm{L}$ has been recognized in many areas of Pakistan, especially in Punjab $[9,26]$. In 2001, a national survey of arsenic affected drinking groundwater sources was carried out in 35 out of 104 districts in Pakistan [107]. Out of 8712 samples $9 \%$ had arsenic concentrations above $10 \mu \mathrm{g} / \mathrm{L}$ guideline value set by the WHO [20] and $0.70 \%$ were above $50 \mu \mathrm{g} / \mathrm{L}$. However, the analysis of 848 samples (out of 8712 ) shows arsenic concentrations over $10 \mu \mathrm{g} / \mathrm{L}$ in almost $30 \%$ of samples and $7 \%$ above $50 \mu \mathrm{g} / \mathrm{L}$.

According to the WHO in developed countries the maximum admissible concentration of As in drinking water is $10 \mu \mathrm{g} / \mathrm{L}$; however, the developing countries, where arsenicosis is more widespread, are still using the previous guideline value $(50 \mu \mathrm{g} / \mathrm{L})$ due to the lack of facilities to analyze smaller concentrations precisely [20]. The Public Health Engineering Department of Pakistan, in collaboration with UNICEF, conducted a survey for As concentration in drinking water supply wells in 2001 and disclosed some hotspots of As-enriched groundwater occurring in parts of the Indus alluvial basin. Muzaffargarh district was one of the As-enriched hotspots also identified [108]. The same was confirmed later in another study from Muzaffargarh district, which revealed that the As concentration as high as $906 \mu \mathrm{g} / \mathrm{L}$ was present, whereas $58 \%$ of samples were found above $10 \mu \mathrm{g} / \mathrm{L}$ [26]. Either direct 


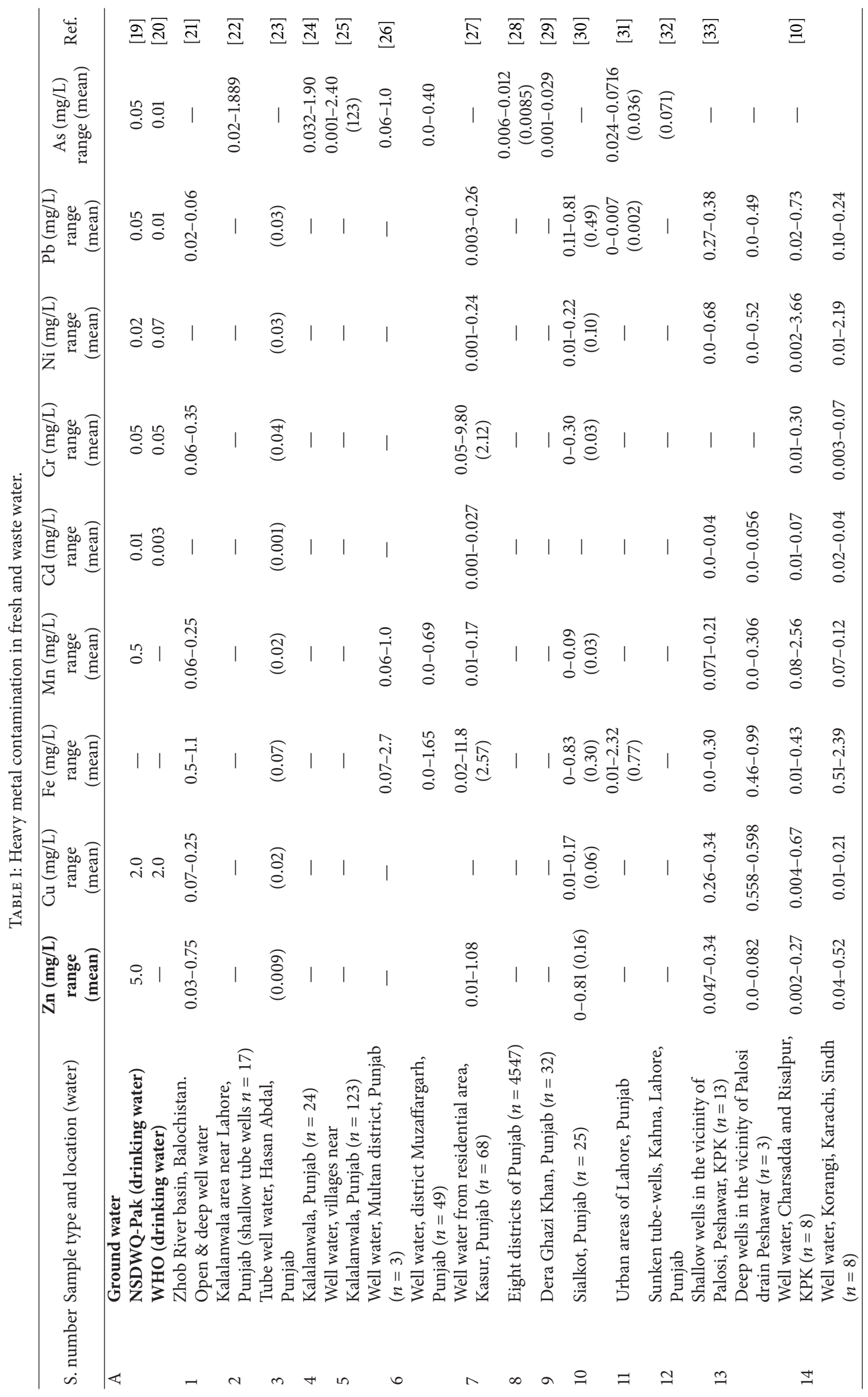




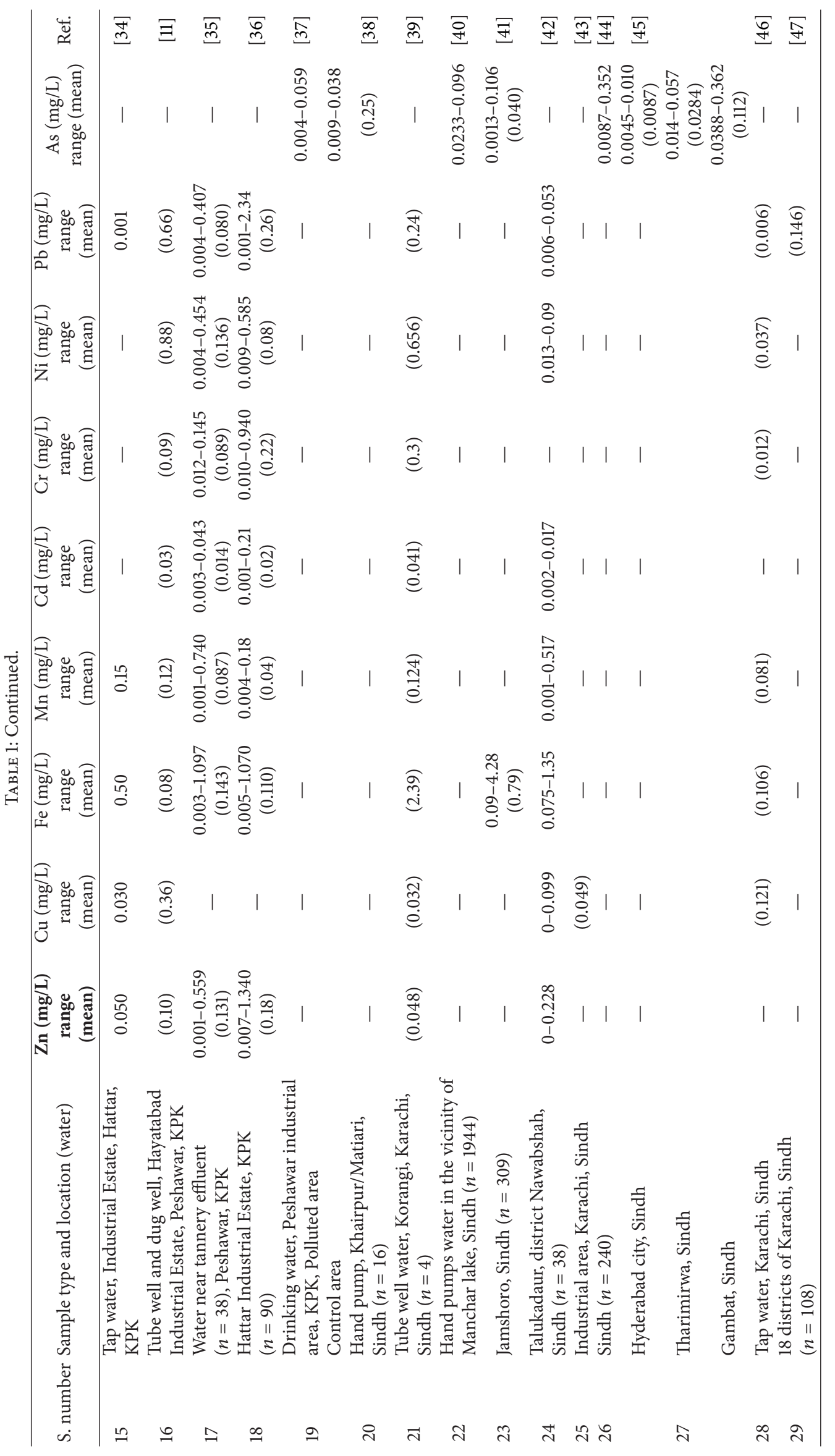




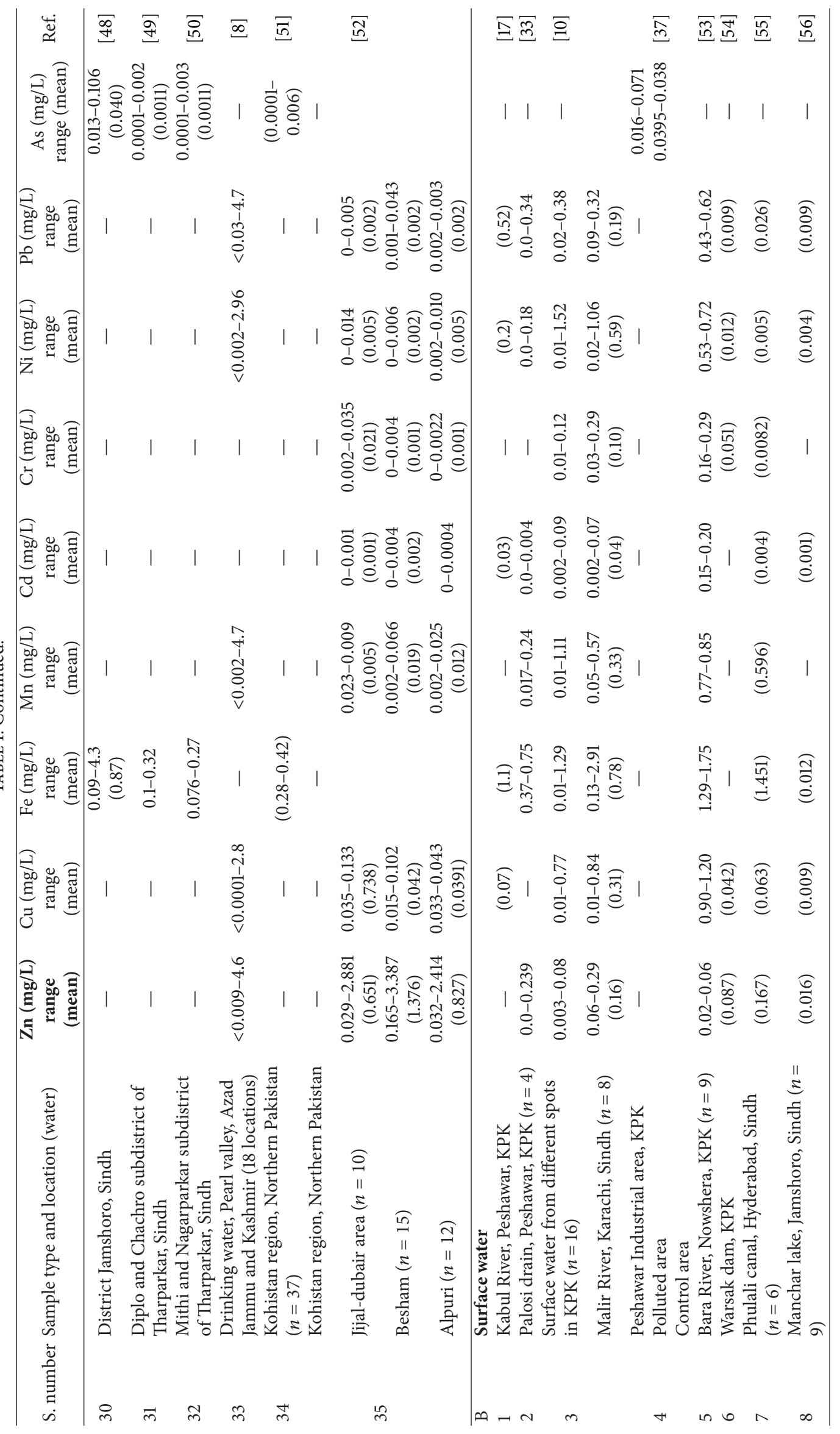




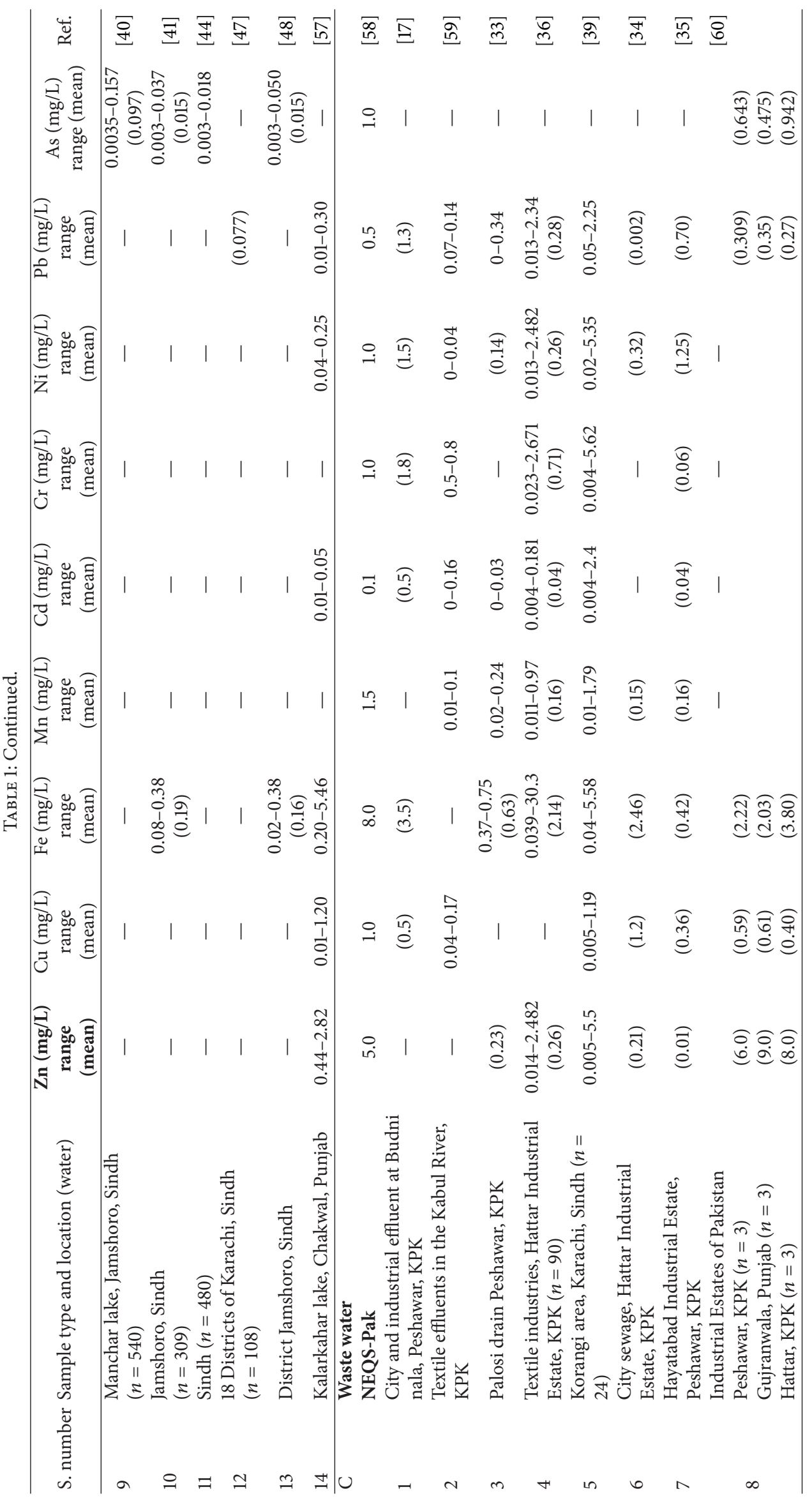




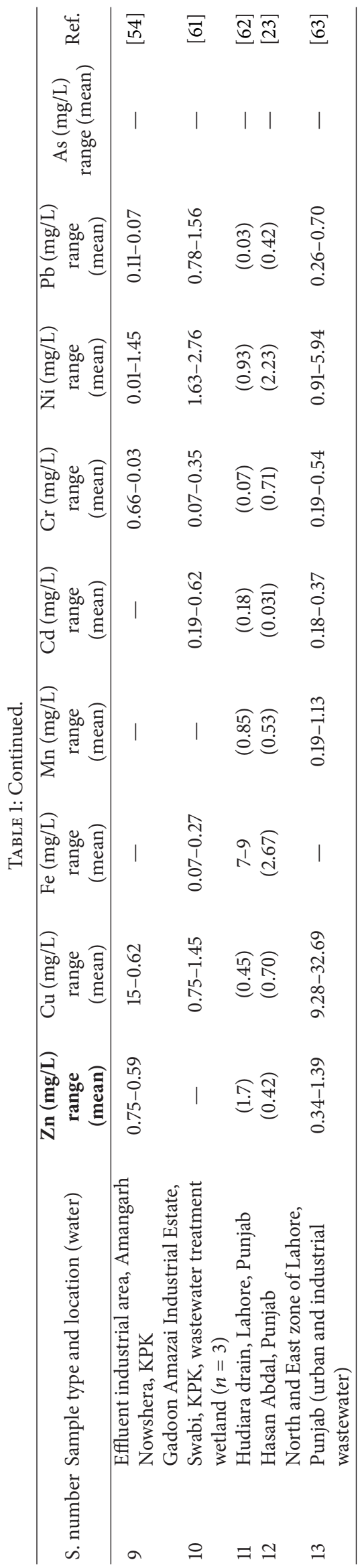




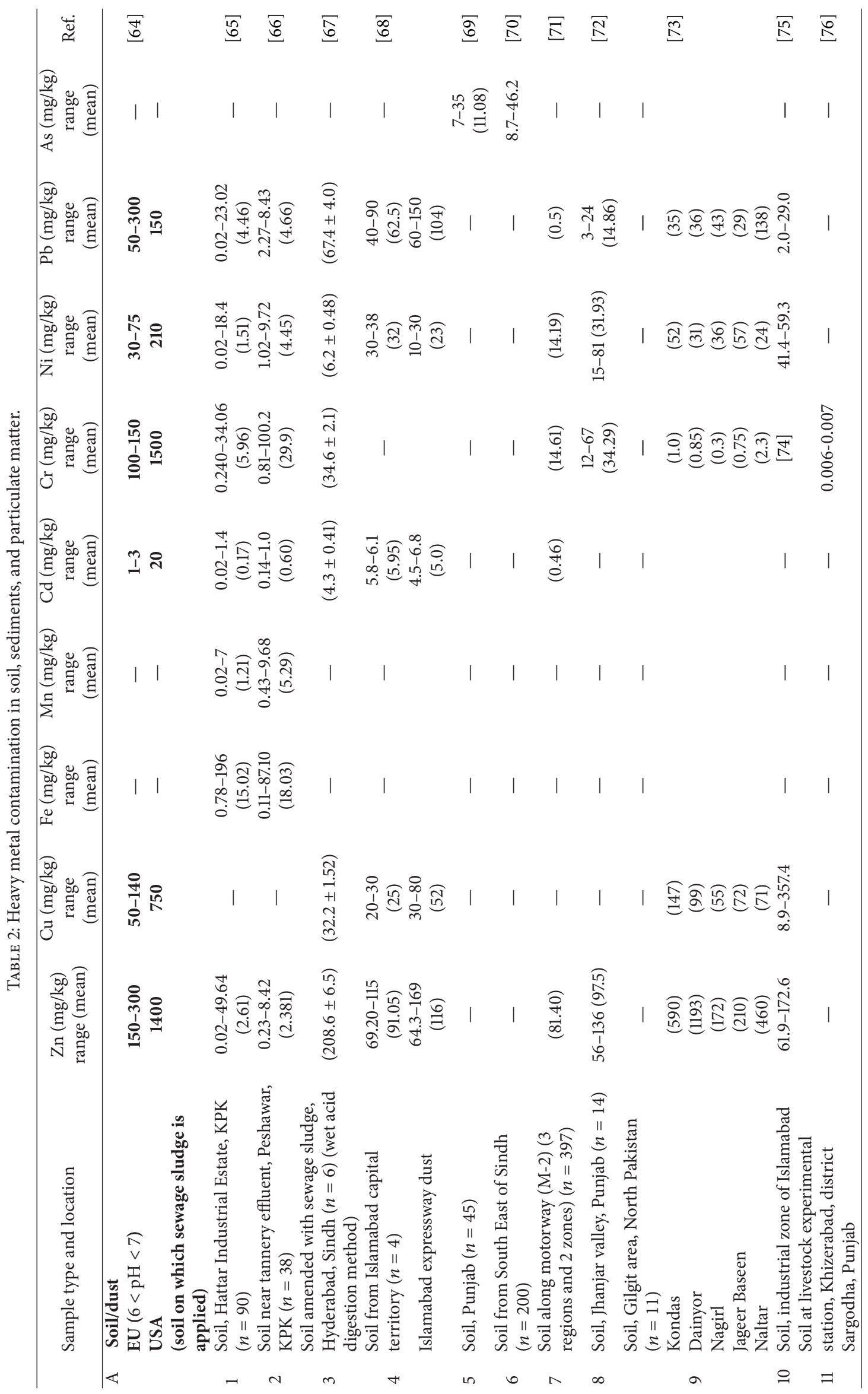




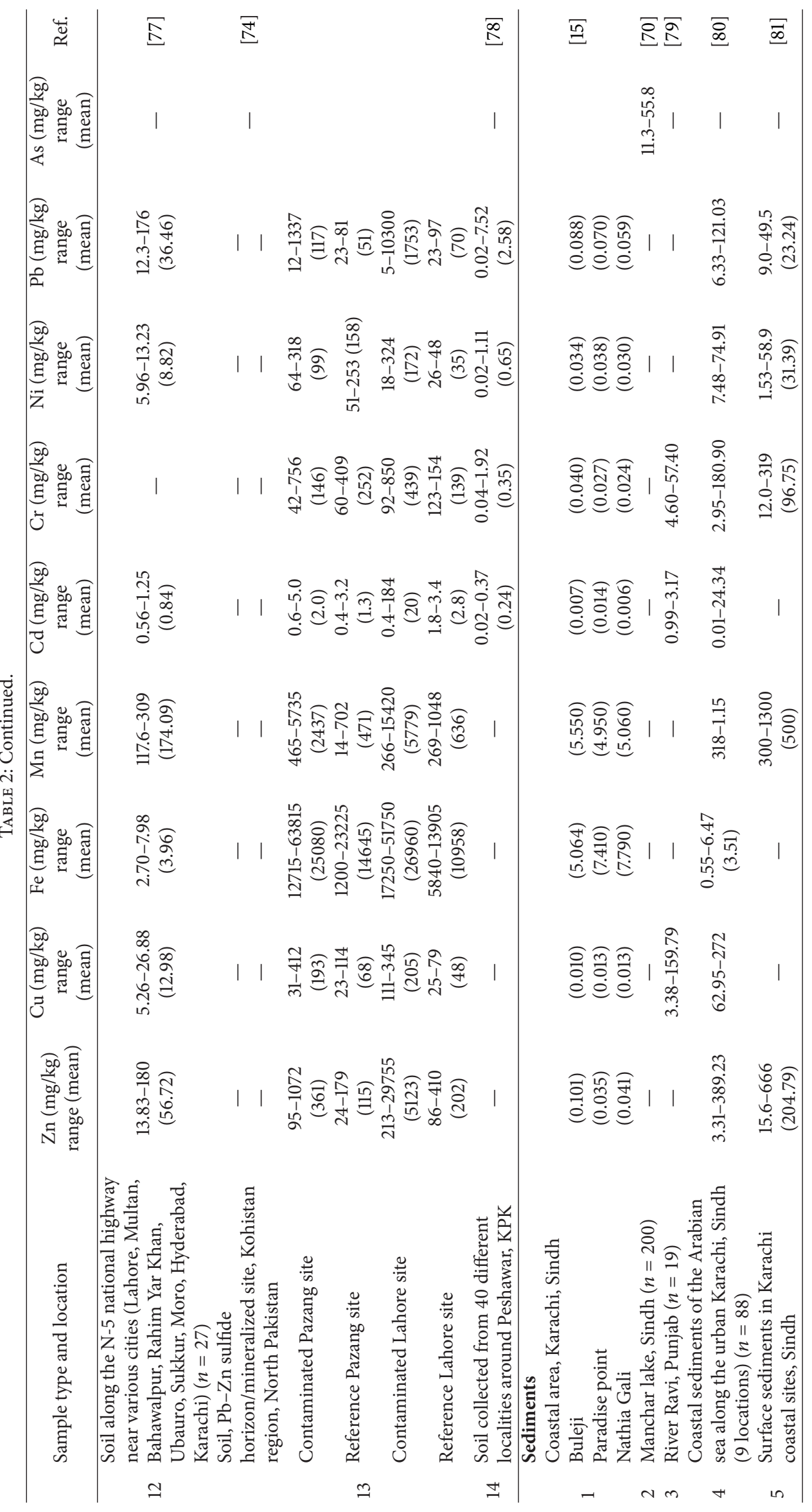




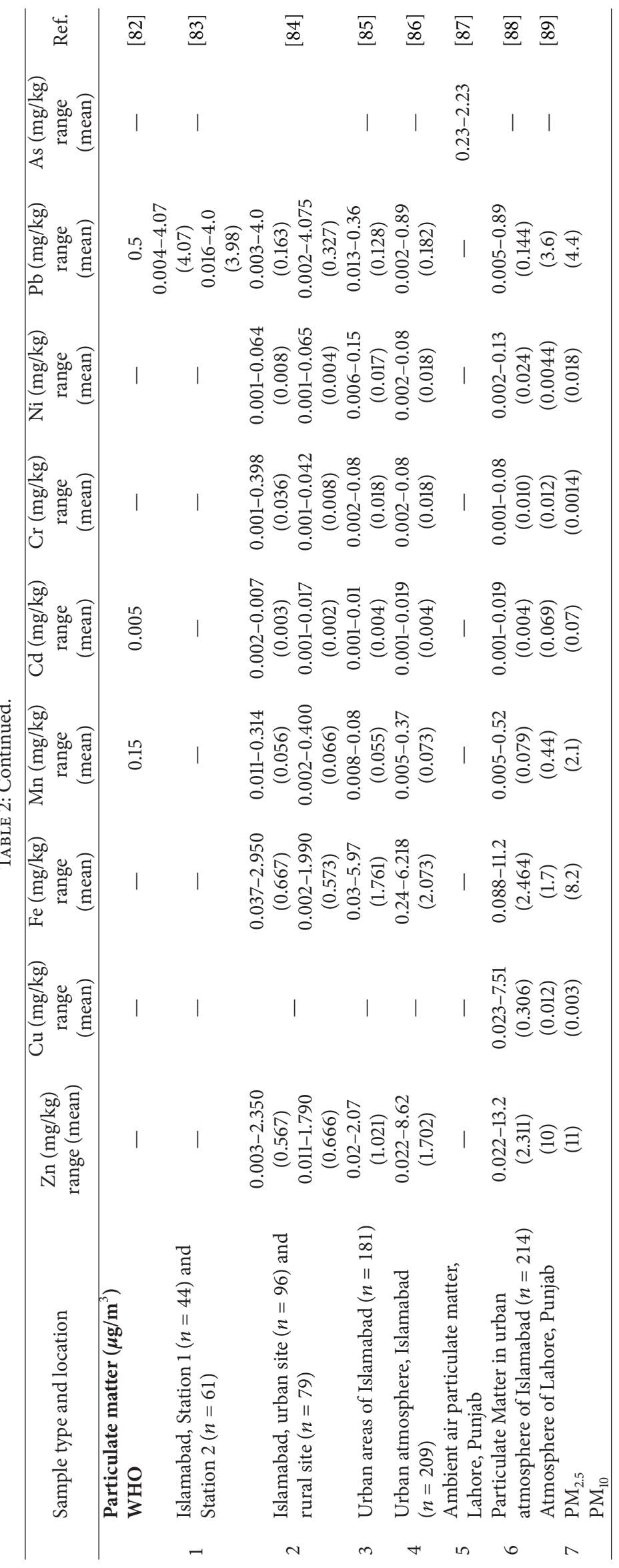




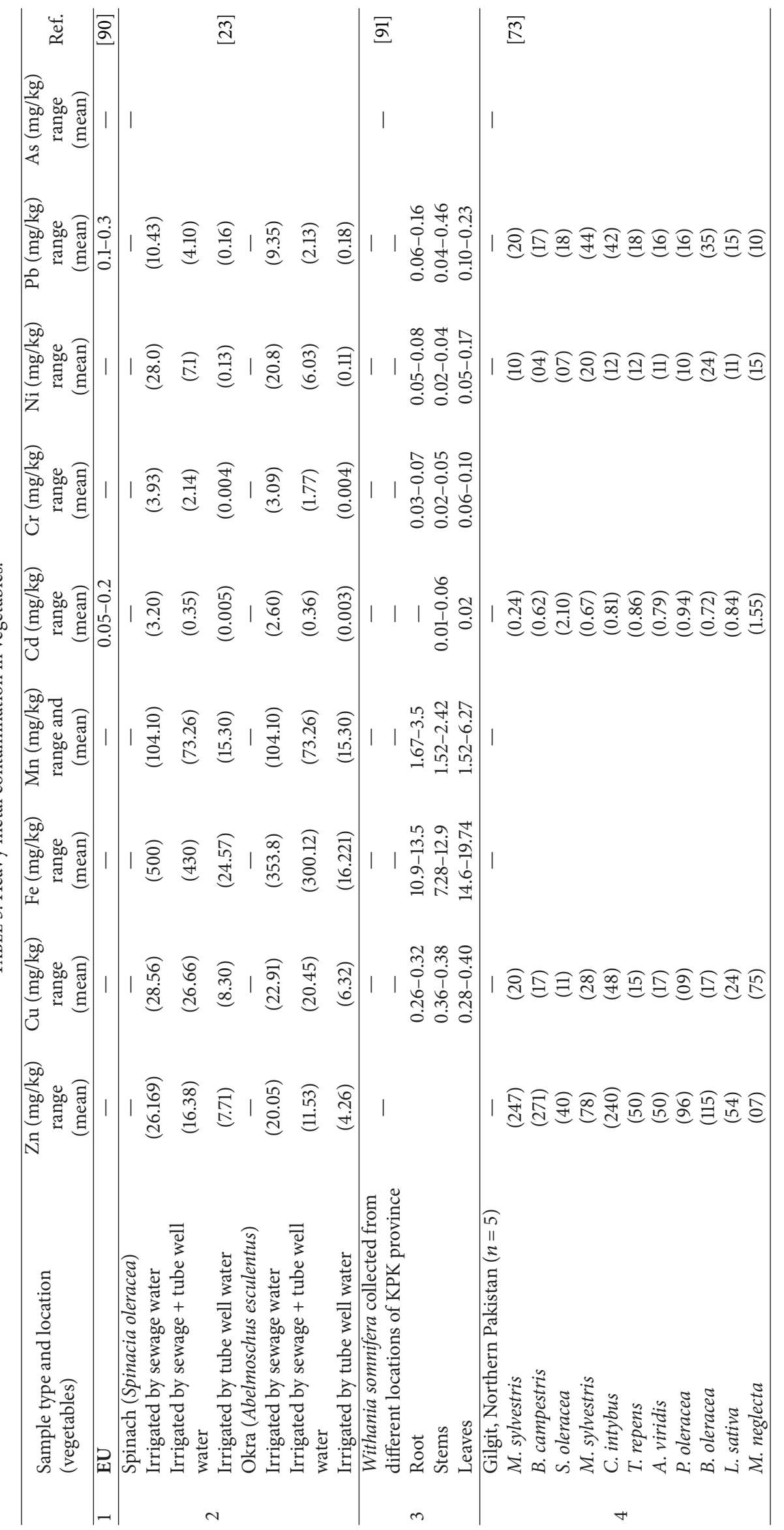




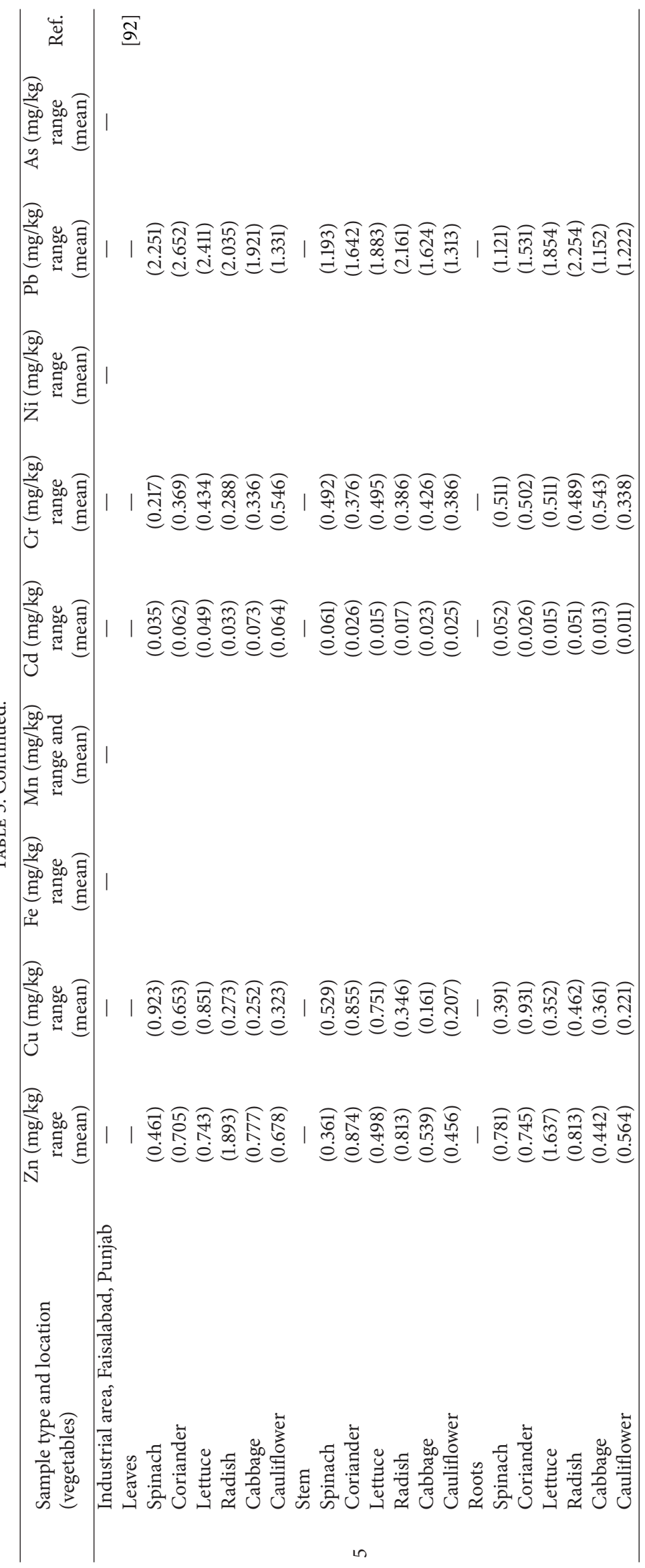




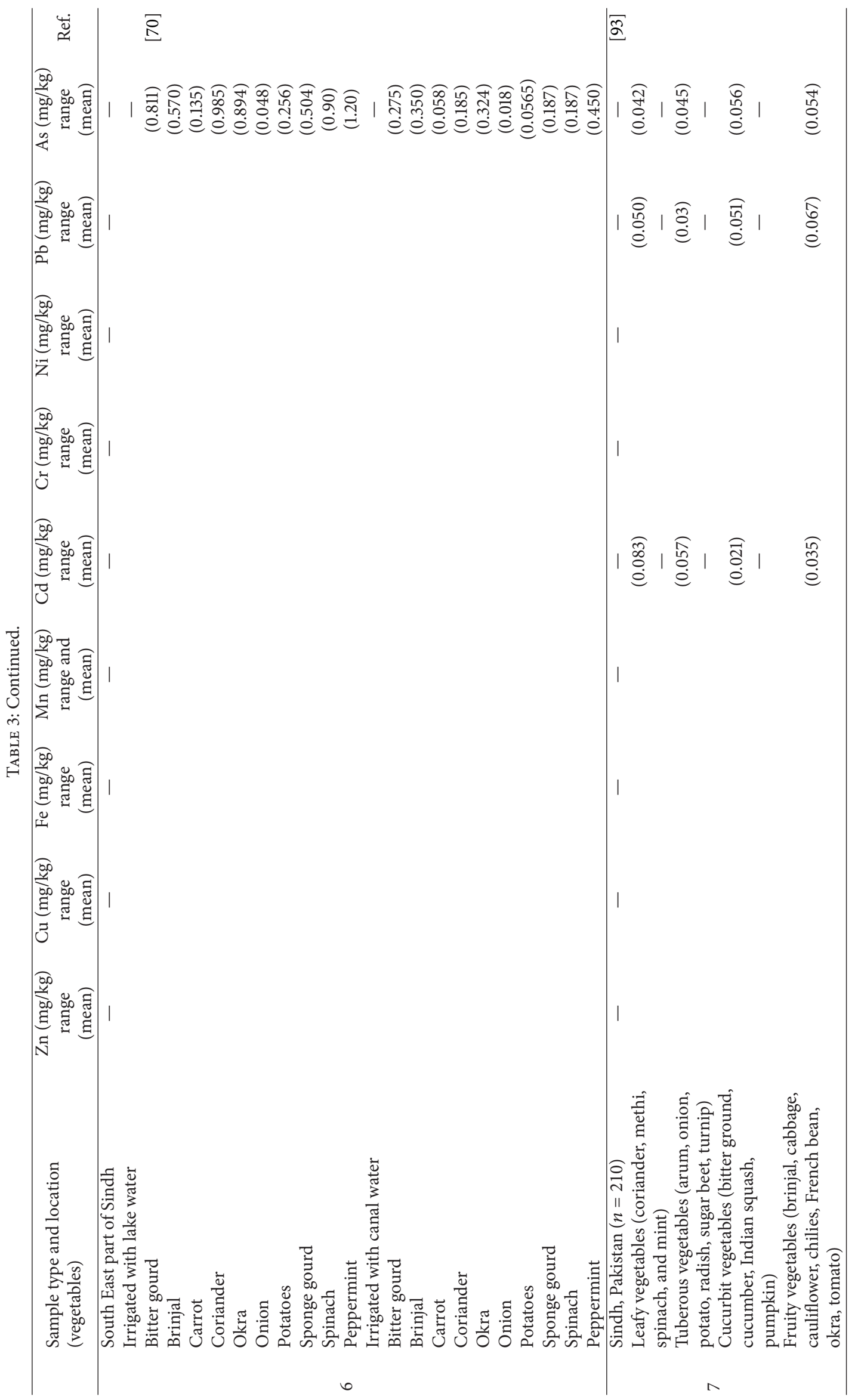




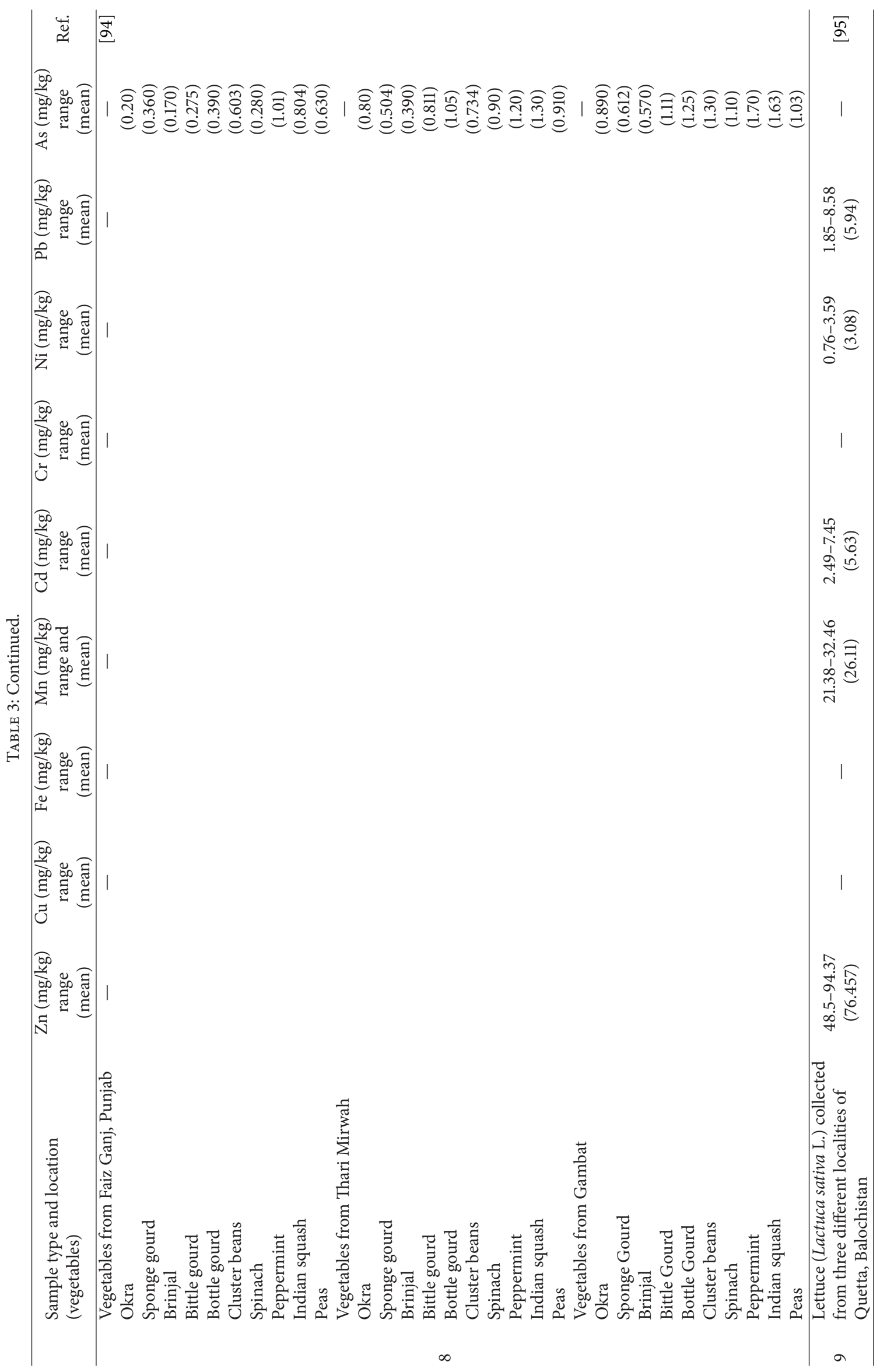




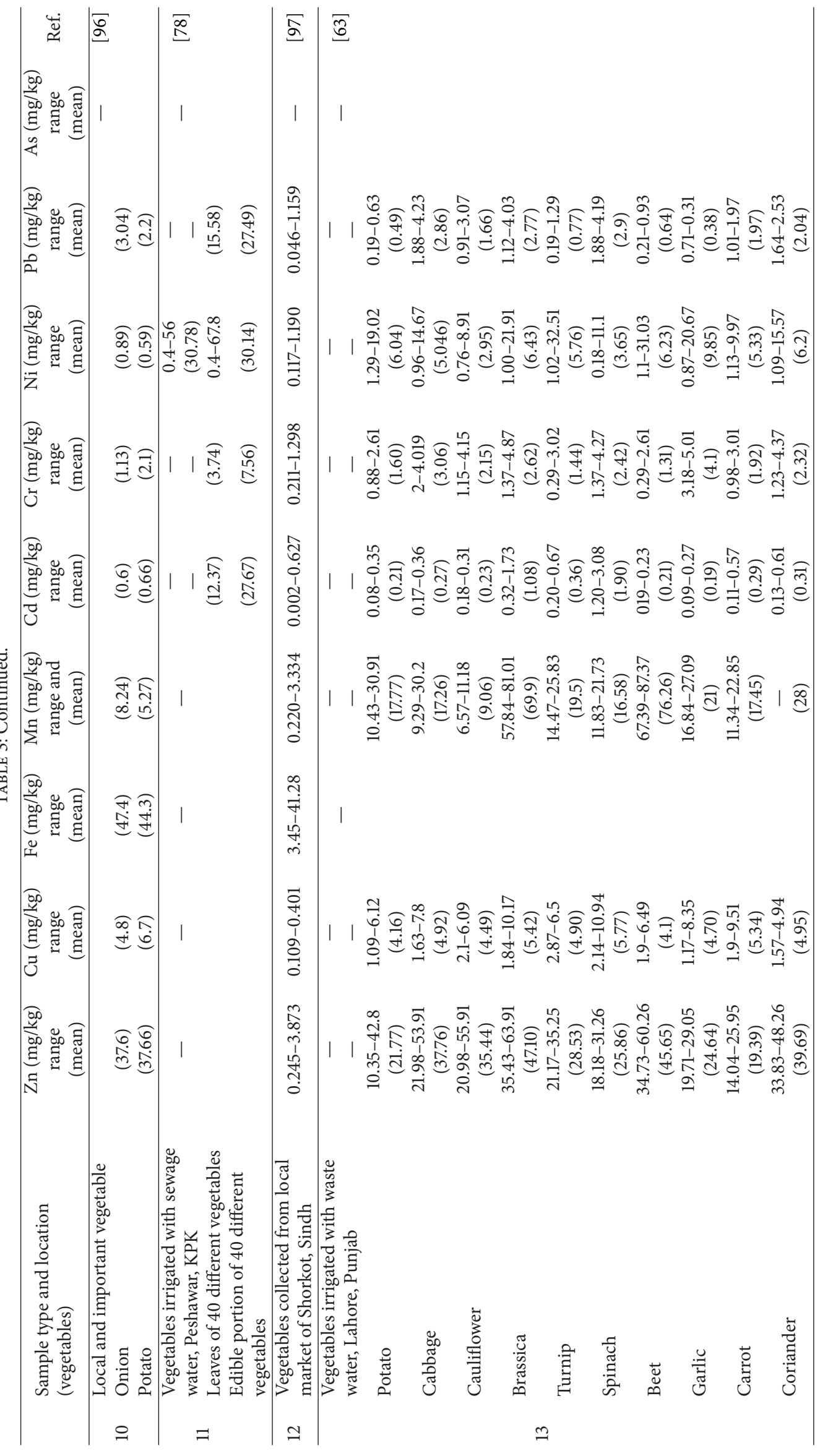



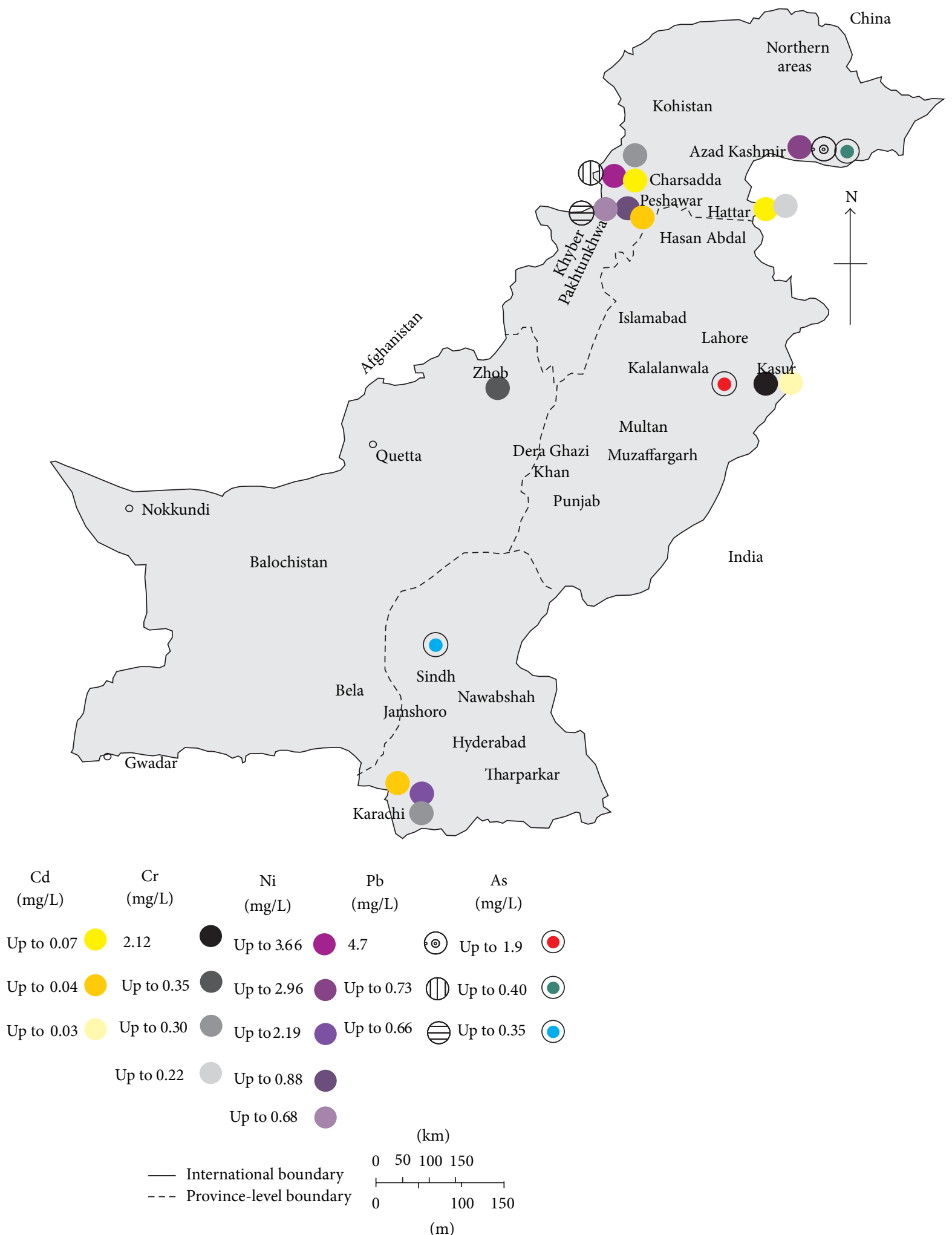

FIGURE 1: Map of Pakistan showing the $\mathrm{Cd}, \mathrm{Cr}, \mathrm{Ni}, \mathrm{Pb}$, and As concentration in ground water (mean values; where mean value is not available, the highest values are used). 


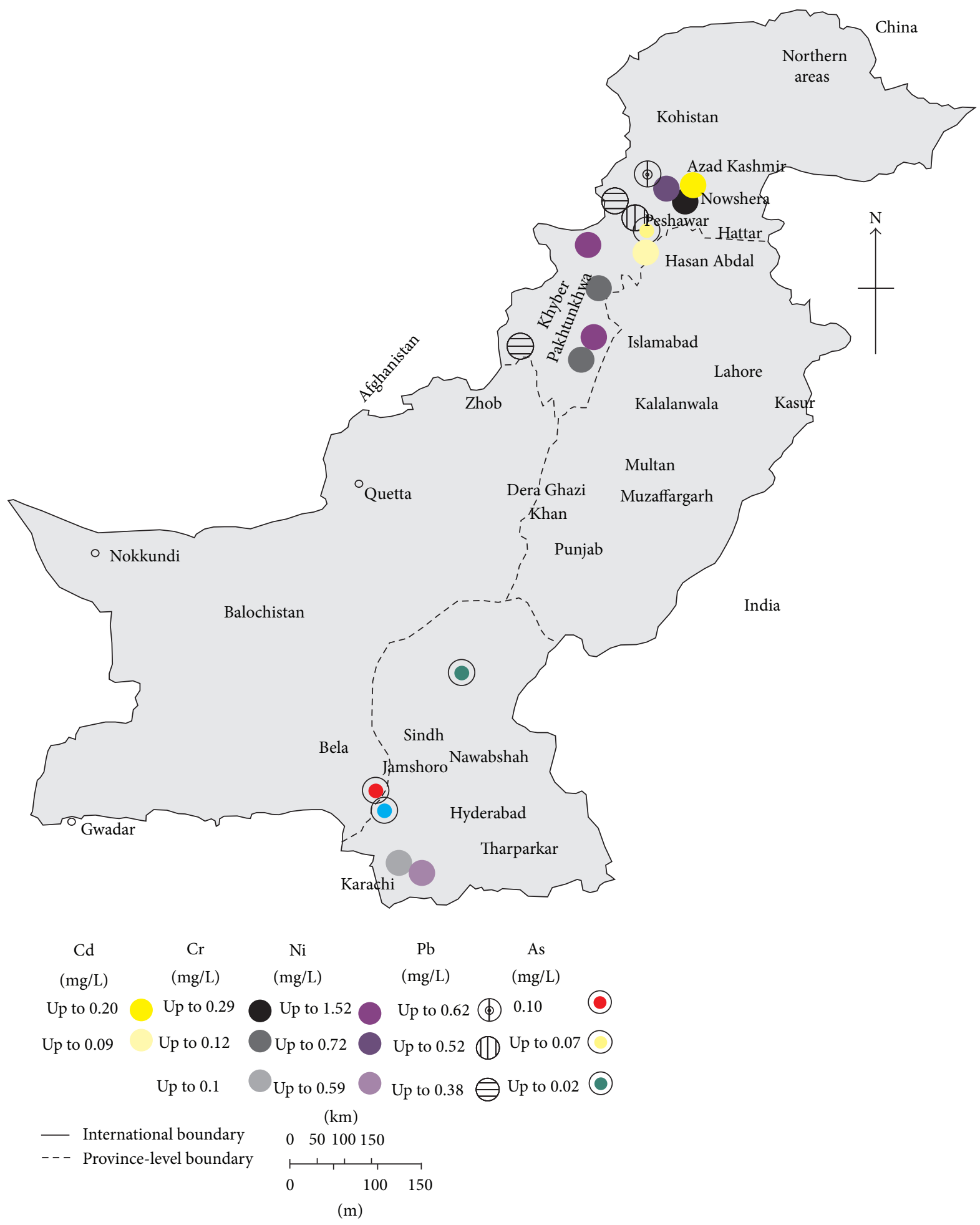

FIGURE 2: Map of Pakistan showing the $\mathrm{Cd}, \mathrm{Cr}, \mathrm{Ni}, \mathrm{Pb}$, and As concentration in surface water (mean values; where mean value is not available, the highest values are used).

contamination with industrial or agricultural chemicals or some other anthropogenic influences have been indicated by the spatial distribution of As-rich shallow groundwater [26]. However, in 2007, the enormously high concentrations of As were found in shallow-well waters in four villages from the western and eastern parts of the Punjab, $2400 \mu \mathrm{g} / \mathrm{L}$ in Kalalanwala and Kot Asad Ullah, $883 \mu \mathrm{g} / \mathrm{L}$ in Shamkey Bhatian, $672 \mu \mathrm{g} / \mathrm{L}$ in Manga Mandi, and $681 \mu \mathrm{g} / \mathrm{L}$ in Waran Piran Wala (Table 1, Figure 1) [25]. Arsenic in drinking water causes a widespread concern in southern part of Pakistan, 


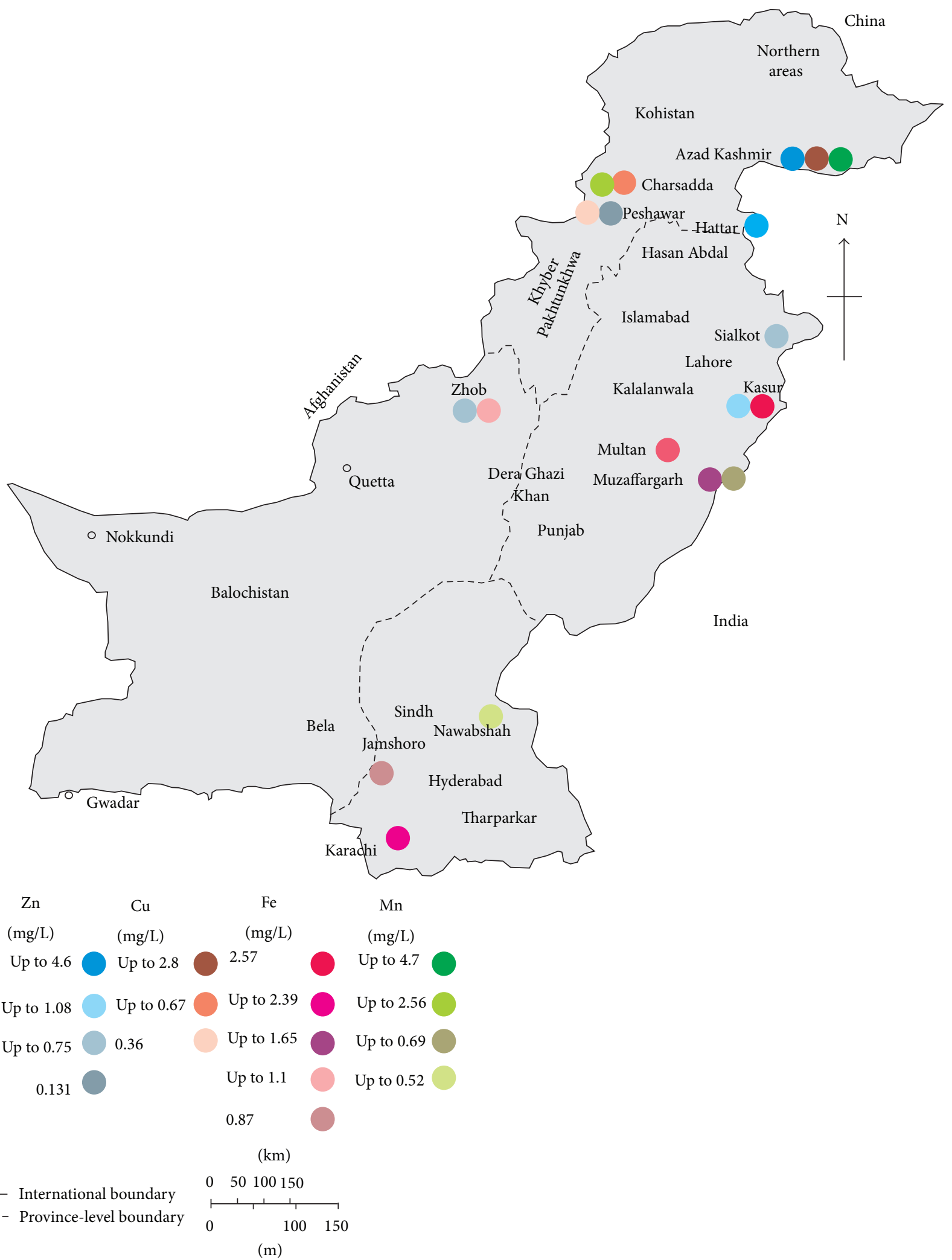

FIGURE 3: Map of Pakistan showing the $\mathrm{Zn}, \mathrm{Cu}, \mathrm{Fe}$, and $\mathrm{Mn}$ concentration in ground water (mean values; where mean value is not available, the highest values are used). 


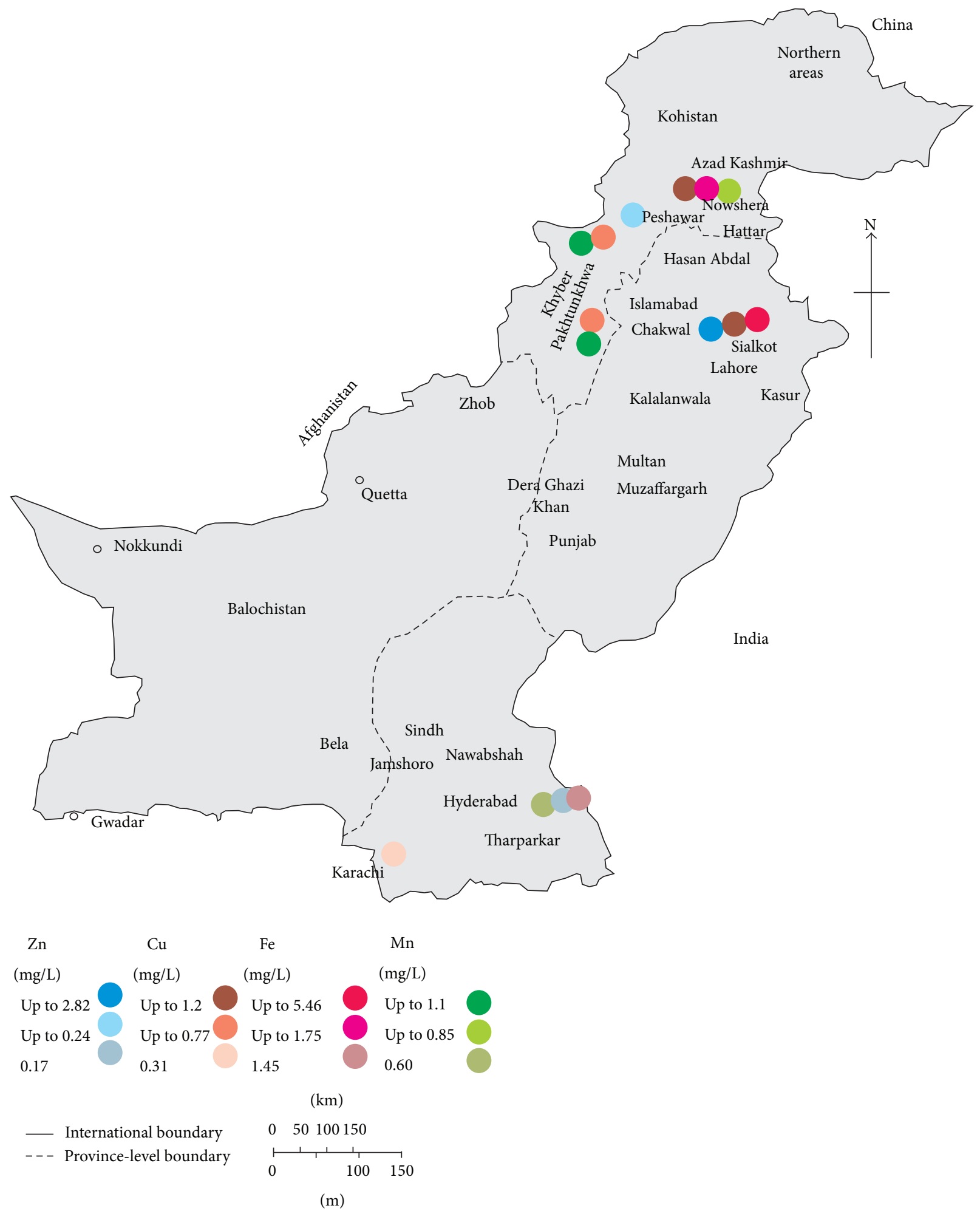

FIGURE 4: Map of Pakistan showing the $\mathrm{Zn}, \mathrm{Cu}, \mathrm{Fe}$, and Mn concentration in surface water (mean values; where mean value is not available, the highest values are used). 
where underground and surface water used for drinking and irrigation are contaminated with As [40]. In the same context, the range of As concentrations in Manchar lake (largest freshwater lake in Pakistan) water of southern part of Sindh was found in the range of $35.2-158 \mu \mathrm{g} / \mathrm{L}$ (mean $97.5 \mu \mathrm{g} / \mathrm{L}$ ), which is 3- to 15 -folds higher than permissible limit of WHO [40]. Similarly in Jamshoro, Sindh, the highest content of As in surface water sample was found to be $50 \mu \mathrm{g} / \mathrm{L}$ [48].

As concentrations of soil samples are relatively higher in surface soils than in deep soils from the same location. The highest average As content in the soils of the agricultural areas of Sindh (irrigated with As-rich lake water) was found to be $46.2 \mathrm{mg} / \mathrm{kg}$ [70] followed by $35 \mathrm{mg} / \mathrm{kg}$ in surface soil collected from various regions of Punjab [69]. The author proposed the contribution of air pollutants derived from coal combustion and the use of fertilizers for high levels of As in the surface soils [69]. In some parts of the Sindh total As level in sediment and soil irrigated with lake water was higher than the Threshold Effects Level as reported by Interim sediment quality assessment values [109] and USEPA [110]. The mean values of total As in Manchar lake sediment were found in the range of 11.3-55.8 [70]. Pakistan Environmental Protection Agency reported arsenic in ambient air particulate matter in the Lahore district in the range of $230-2230 \mathrm{ng} / \mathrm{m}^{3}$ [87], which is much higher than those reported in the other areas in the world, for example, $91-512 \mathrm{ng} / \mathrm{m}^{3}$ in Calcutta, India [111], $25 \mathrm{ng} / \mathrm{m}^{3}$ in Wuhan City, China [112], and 1.2-44 ng/m $\mathrm{m}^{3}$ in Los Angles, USA [113].

Several studies on the linear relationship between As contents of vegetation and concentrations in soils of both total and soluble species suggest that plants take up As passively with the water flow [114]. Plants may accumulate extremely large amounts of As depending on the location and pollution source [114]. It was observed that the use of As-rich irrigation water and soil affected plant height, crop yield, and development of root growth $[115,116]$. In south east part of the Sindh the higher accumulation of As was found in spinach, coriander, and mint leaves in the range of $0.90-1.20 \mathrm{mg} / \mathrm{kg}$, while lower uptake of As was observed in onion, carrot, and potato, in the range of $0.048-0.256 \mathrm{mg} / \mathrm{kg}$ (Table 3) [70]. The daily As intake from food stuffs in As affected (irrigated with lake water) and unaffected (irrigated with canal water) area was found to be 343.5 and $144.7 \mu \mathrm{g} / \mathrm{day}$ in adults, respectively [70]. This daily dietary intake of total As from food composites by adults is higher than in other countries, 59.2 $\mu \mathrm{g}$ (adult males) and 34.1 $\mu \mathrm{g}$ (adult females) in Canada [117].

2.2. Cadmium. Cadmium (Cd) is an element of great concern from toxicity point of view and its exposure can cause both chronic and acute health effects in living organisms. Cd occurs naturally in the earth's crust and in ocean water [98]. The terrestrial abundance of Cd on average is $0.1-0.2 \mathrm{mg} / \mathrm{kg}$, whereas, in ocean waters, it ranges from $<5$ to $110 \mathrm{ng} / \mathrm{L}$ on average [98]. Cd and its compounds are carcinogenic to humans and are classified as Group 1 by International Agency for Research on Cancer, as Cd and its compounds cause cancer of the lung, and positive associations have been observed for cancers of the kidney and of the prostate [98]. Cd intoxication can also leads to pulmonary damages, kidney damage, skeletal damage, and itai-itai diseases [118, 119]. In drinking water the tolerable concentration set by WHO is $0.003 \mathrm{mg} / \mathrm{L}$ for Cd [20]. In Pakistan, high Cd concentration in drinking water may be from effluents discharges of marbles, steel, and aluminium industries as well as from mining and metal plating [11]. The observed concentration of $\mathrm{Cd}$ in ground water samples collected from various sites of Pakistan ranged from 0.001 to $0.21 \mathrm{mg} / \mathrm{L}$ (Table 1) $[23,36]$. The highest value of $0.21 \mathrm{mg} / \mathrm{L}$ was reported in the samples collected from tube well water of Hayatabad Industrial Estate, Khyber Pakhtunkhwa (KPK) province with an average of $0.02 \mathrm{mg} / \mathrm{L}$ [36]. Similarly, the Cd concentration in surface water samples shows large variation throughout the country and ranges between below detection limit to $0.2 \mathrm{mg} / \mathrm{L}$ (Figure 2) [53, 56]. Moreover, in surface water sample (Kalar Kahar lake, Chakwal) Cd remained undetectable in the months of MarchApril; however, it showed seasonal variation in other months of the year (i.e., 0.01-0.05) $\mathrm{mg} / \mathrm{L}$ [57]. The concentration of $\mathrm{Cd}$ in surface water samples collected from various sites in NWFP province (now called KPK) ranged from 0.002 to $0.09 \mathrm{mg} / \mathrm{L}$ (mean $0.02 \mathrm{mg} / \mathrm{L}$ ), the highest value being reported from Kalpani drain. Similarly, Malir River in Karachi (Sindh province) showed variation between 0.002 and $0.07 \mathrm{mg} / \mathrm{L} \mathrm{Cd}$ (mean $0.04 \mathrm{mg} / \mathrm{L}$ ) from the same study [10].

A number of studies show the widespread Cd distribution in wastewater samples collected from various regions of Pakistan (Table 1). The highest concentration of $5.35 \mathrm{mg} / \mathrm{L}$ $\mathrm{Cd}$ in wastewater reported from Korangi area, Karachi [39], exceeded the permissible limit of $0.10 \mathrm{mg} / \mathrm{L}$ set by NEQS-Pak for industrial and sewage wastewater [58]. Moreover, in north and east zones of Lahore, Punjab province, the concentration of Cd in wastewater was also above the safe limit set by NEQS and is in the range of 0.18 to $0.37 \mathrm{mg} / \mathrm{L}$ [63]. In another study on wetland efficiency for heavy metal removal from industrial wastewater in Gadoon Amazai Industrial Estate, Swabi (KPK province), showed the variation of $\mathrm{Cd}$ in the range of $0.19-$ $0.62 \mathrm{mg} / \mathrm{L}$ [61].

Natural and anthropogenic sources contribute to the levels of $\mathrm{Cd}$ found in soil and sediments, for example, sources like mine/smelter wastes, phosphate fertilizers, or sewage sludge, and municipal waste landfills are the noteworthy [98]. On worldwide level the reported sediment concentrations of Cd range from 0.03 to $1 \mathrm{mg} / \mathrm{kg}$ in marine sediments and as high as $5 \mathrm{mg} / \mathrm{kg}$ in river and lake sediments ([98] and references therein).

In the soil of various regions of Pakistan, it is observed that there is a large variation in Cd level among the chosen sites, which ranged between 0.02 and $184 \mathrm{mg} / \mathrm{kg}$ from normal soil to contaminated soil with mining or other activities (Table 2) [74, 78]. In another study from district Sargodha, the highest concentrations of $\mathrm{Cd}$ in the soil was found to be $6.74 \mathrm{mg} / \mathrm{Kg}$ and the higher values of $\mathrm{Cd}$ in soil suggested the possible risk of $\mathrm{Cd}$ entering into higher food chain which was reflected by the $\mathrm{Cd}$ accumulation by forage in the range of 1.14 to $4.20 \mathrm{mg} / \mathrm{kg}$ [76]. In the soil of Islamabad Territory, capital city of Pakistan, and the dust road along Islamabad 
Expressway, Cd concentrations of 5.8-6.1 and $4.5-6.8 \mathrm{mg} / \mathrm{kg}$, respectively, have been found; these values are higher than that of many cities around the world, comparable to AqabaShuna Highway (Jordan) and Istanbul Highway (Turkey) [68, $120,121]$.

Siddique et al. reported the highest concentration of $\mathrm{Cd}$ in sediments, that is, $24.34 \mathrm{mg} / \mathrm{Kg}$ at Gizri Creek location at the most downstream part of the Malir River, Karachi, followed by the second highest value $21.34 \mathrm{mg} / \mathrm{Kg}$ at the Lyari location, Karachi, where the Lyari River drains the city waste into the Arabian sea [80]. Moreover, in the sediments of the River Ravi, Punjab province, the mean Cd concentrations fluctuated between a maximum value of $3.17 \mathrm{mg} / \mathrm{Kg}$ (Shahdera Bridge) and a minimum mean value of $0.99 \mathrm{mg} / \mathrm{Kg}$ at Lahore Siphon, Punjab [79]. Toxic metals can enter the human body by consumption of contaminated food crops, water, or inhalation of dust [122]. Various studies from Pakistan suggest the transfer of heavy metals to food crops or vegetables $[16,63,73,95,123]$. Critical toxic level of $5.63 \mathrm{mg} / \mathrm{kg}$ (average) with reference/control value $2.498 \mathrm{mg} / \mathrm{kg}$ of Cd in lettuce irrigated with different levels of wastewater has been reported in Quetta city, Balochistan province [95]. The accumulation of elevated concentration of $\mathrm{Cd}$ in lettuce was attributed to the use of wastewater effluents for their cultivation [95]. Cd concentration recorded by different researchers in other parts of the country for various vegetables (including lettuce) clearly indicates the critical toxic level of Cd uptake (Table 3). In Gilgit, Northern Pakistan, the mean concentrations of $\mathrm{Cd}$ ranged from 0.24 to $2.1 \mathrm{mg} / \mathrm{kg}$ in all vegetable samples, being the highest in S. oleracea and the lowest concentration in $M$. sylvestris [73].

Respiration is the one of the two pathways for many metals to enter humans and ingestion with food is the other. Heavy metals in air are a matter of great concern; as we breathe, the polluted air directly transfers the contaminant in to the lungs. Keeping in view of the Cd health impacts, the WHO proposed a guideline value of $5 \mathrm{ng} / \mathrm{m}^{3}$ in air [82]. Heavy metals in atmosphere are usually present as a part of fine particles called particulate matter $\left(\mathrm{PM}_{10}\right.$ or $\left.\mathrm{PM}_{2.5}\right)$. The IARC Working Group recently classified outdoor air pollution and particulate matter from outdoor air pollution as carcinogenic to humans (IARC Group 1) [124]. The majority of the studies from Pakistan reports the air borne $\mathrm{Cd}$ concentration of less than $5 \mathrm{ng} / \mathrm{m}^{3}$ (on average basis) in suspended particulate matter (Table 1). However, a report from Lahore shows the annual mean Cd concentration of 69 $\mathrm{ng} / \mathrm{m}^{3}$ in $\mathrm{PM}_{2.5}$ [89].

2.3. Lead. Lead $(\mathrm{Pb})$ exposure in children and adults can cause a wide spectrum of health problems, ranging from small effects on metabolism and intelligence to convulsions, coma, renal failure, and death [125]. As per International Agency for Research on Cancer evaluation, inorganic $\mathrm{Pb}$ compounds are probably carcinogenic to humans (Group $2 \mathrm{~A}$ ), whereas organic lead compounds are not classifiable as to their carcinogenicity to humans (Group 3) [126]. Lead is found at low concentrations in the earth's crust predominantly as lead sulfide (galena), but the widespread occurrence of lead in the environment is largely the result of anthropogenic activity. $\mathrm{Pb}$ enters the environment at any stage from its mining to its final use, and it contaminates crops, soil, water, food, air, and dust [126]. In Pakistan, most of the ground water samples exceeded the permissible limit of $0.01 \mathrm{mg} / \mathrm{L}$ set by WHO for drinking water (Table 1) and $\mathrm{Pb}$ concentration ranges from $<0.001$ to $4.7 \mathrm{mg} / \mathrm{L}$ in various regions (Table 1). Detectable dissolved concentration of $\mathrm{Pb}$ in sample collected from Pearl valley of Azad Jammu Kashmir (AJ\&K) ranged between 1.8 and $4.7 \mathrm{mg} / \mathrm{L}$ [8]. The WHO reference value guidelines comparison has revealed that the concentrations of $\mathrm{Pb}$ were 466 higher in water samples taken from the well at Kharick II (South, AJ\&K) $[8,20]$. In Hattar Industrial Estate (KPK), most of the ground water samples exceeded the critical level of $0.01 \mathrm{mg} / \mathrm{L}$ with an average of $0.26 \mathrm{mg} / \mathrm{L}$ [36]. Similarly, in Sialkot, Punjab province, $100 \%$ of the samples analyzed exceeded the critical level $(0.01 \mathrm{mg} / \mathrm{L})$ for lead in drinking water [30]. Individual studies revealed that a higher proportion of water sources in the country had $\mathrm{Pb}$ above the safe limits, in both surface and ground waters (Table 1, Figures 1 and 2). In surface waters, significantly higher $\mathrm{Pb}$ average concentration has been reported, where the highest value of $0.62 \mathrm{mg} / \mathrm{L}$ was observed in Bara River water in Akbarpura area of district Nowshera, KPK [53]. Waste water sample analysis for $\mathrm{Pb}$ concentrations from more than $50 \%$ studies shows higher values than admissible $\mathrm{Pb}$ level of $0.50 \mathrm{mg} / \mathrm{L}$ in waste water set by National Environmental Quality Standard Pakistan (Table 1) [58]. The highest $\mathrm{Pb}$ contamination $(2.34 \mathrm{mg} / \mathrm{L})$ was reported in the samples collected from three textile industries located in Hattar Industrial Estate, KPK [36]. As a consequence, waste water channels have high content of $\mathrm{Pb}$ rendering them the most hazardous for soil, plant, and other organisms including human beings.

In soil, Table 2 indicates that the $\mathrm{Pb}$ concentration is well below the acceptable level of $\mathrm{Pb}(50-300 \mathrm{mg} / \mathrm{Kg})$ in normal soil on which sewage sludge is applied by European Union [64]. The only exception in the above statement is where the highest $\mathrm{Pb}$ concentration of $103000 \mathrm{mg} / \mathrm{kg}$ (mean $1753 \mathrm{mg} / \mathrm{kg}$ ) was detected in contaminated soil under mining activities with mean reference soil value of $70 \mathrm{mg} / \mathrm{kg}$ from Kohistan region, Gilgit Baltistan province [74]. Moreover, the contamination of heavy metals especially $\mathrm{Pb}$ in roadside soil is related to the traffic density on the roads [127]. In Pakistan, $\mathrm{Pb}$ concentration along National Highway-5 ranges from 12 to $176 \mathrm{mg} / \mathrm{kg}$ with a mean of $36.45 \mathrm{mg} / \mathrm{Kg}$ and the highest concentration of $176 \mathrm{mg} / \mathrm{kg}$ was found near the bypass road of Hyderabad city, Sindh Province, which is the fifth largest industrial city of the country [77].

In various coastal regions of Pakistan, the highest levels of $\mathrm{Pb} 121 \mathrm{mg} / \mathrm{kg}$ were found in the coastal sediments of the Arabian sea along the urban Karachi [80] followed by $49.5 \mathrm{mg} / \mathrm{kg}$ from surficial sediments of Lyari River [81].

Lead has been acknowledged as one of the toxic constituents of airborne PM, with emission levels estimated at 450 million kg per annum from industrial coal and oil combustion and 30 million $\mathrm{kg}$ per annum from natural sources [114]. The variations in the $\mathrm{Pb}$ concentration at some points may be due to traffic burden, brick kilns, and usage of leaded gasoline [68]. Nowadays, the concentration of $\mathrm{Pb}$ in the urban 
atmosphere of Islamabad decreased in recent years due to the use of $\mathrm{Pb}$-free gasoline, although the $\mathrm{Pb}$ content is still at a high level, ranging from 0.002 to $4.7 \mu \mathrm{g} / \mathrm{m}^{3}[83,84]$. In comparison with the WHO air quality guidelines for Europe $\left(<0.5 \mu \mathrm{g} / \mathrm{m}^{3}\right.$, annual average) [82], the local atmosphere of Islamabad appears to face a serious problem of lead pollution (Table 2). Average air lead levels are usually $<0.15 \mu \mathrm{g} / \mathrm{m}^{3}$ at nonurban sites, whereas urban air $\mathrm{Pb}$ levels typically range between 0.15 and $0.5 \mu \mathrm{g} / \mathrm{m}^{3}$ in most European cities [82].

According to European Union the permissible level of lead in vegetables are 0.1 to $0.3 \mathrm{mg} / \mathrm{kg}$ [90]. In Pakistan, the concentrations of $\mathrm{Pb}$ in various vegetable species fluctuating within the range of $0.03-44 \mathrm{mg} / \mathrm{Kg}[73,93]$ and the highest concentration of $\mathrm{Pb}$ were observed in $M$. sylvestris from Gilgit (Northern Pakistan) [73]. Another study showed that edible and leafy portions of vegetables had average $\mathrm{Pb}$ concentration of $27.49 \mathrm{mg} / \mathrm{kg}$ and $15.58 \mathrm{mg} / \mathrm{kg}$, respectively. $83 \%$ of the vegetable samples (edible portion) were found well above the EU safe limit [78]. Most of the studies focused on the vegetables grown on contaminated soils due to anthropogenic activities like mining, such as soil amended with sludge or soil treated with wastewater (Table 3).

2.4. Nickel. Nickel (Ni) is widely distributed in nature and is found in animals, plants, and soil; the concentration of $\mathrm{Ni}$ in soil is approximately in the range of $4-80 \mathrm{ppm}[98,128]$. Large amount of $\mathrm{Ni}$ is released in the atmosphere due to natural as well as anthropogenic activities including fossil fuel consumption, the industrial production (mining, smelting, and refining), use, and disposal of nickel compounds and alloys, and waste incineration [98]. Human exposure to $\mathrm{Ni}$ results from $\mathrm{Ni}$ contaminated food ingestion, water, inhalation, and percutaneous absorption [98, 128]. According to International Agency for Research on Cancer evaluation, $\mathrm{Ni}$ compounds are carcinogenic to humans and are classified as Group 1. Mixtures of Ni metal and compounds cause cancers of the lung and of the nasal cavity and paranasal sinuses [98]. The maximum permissible concentration for $\mathrm{Ni}$ set by WHO in drinking water is $0.07 \mathrm{mg} / \mathrm{L}$ [20], whereas National Standards for Drinking Water Quality, Pakistan (NSDWQPak), suggest the guideline value of $0.02 \mathrm{mg} / \mathrm{L}$ [19]. The concentration of Ni varies from $<0.001-3.66 \mathrm{mg} / \mathrm{L}$ in ground water to $<0.001-1.52 \mathrm{mg} / \mathrm{L}$ in surface water in Pakistan [10]. It was observed that, in most of the cases, groundwater is contaminated with $\mathrm{Ni}$ beyond the contamination level set by NSDWQ-Pak or WHO (Table 1). Similarly, 75\% of the surface water samples from the largest city of the country (Karachi) exceed the limits [10]. In a study from Lahore (North and East zone), the wastewater samples were collected to evaluate the waste water irrigation impact on vegetables. The Ni concentration was found to be the highest than the reported studies from Pakistan and ranged between 0.91 and $5.94 \mathrm{mg} / \mathrm{L}$ and exceeded the permissible limit of $1.0 \mathrm{mg} / \mathrm{L}$ set by National Environmental Quality Standards, Pakistan $[58,63]$.

In soil, the highest concentration of $\mathrm{Ni}$ is $324 \mathrm{mg} / \mathrm{kg}$ (mean $172 \mathrm{mg} / \mathrm{kg}$ ) from contaminated Lahore site, while mean reference value of $70 \mathrm{mg} / \mathrm{kg}$ ( $\mathrm{Pb}-\mathrm{Zn}$ sulfide horizon/mineralized site) in Kohistan region was found, which is far more than the permissible limits set by EU or USA standards of soil on which sewage sludge can be applied (3075 and $210 \mathrm{mg} / \mathrm{kg}$ ), respectively $[63,64]$. This was attributed to the dispersion of metals due to mining and may pose potential threats to local communities of Kohistan region. Moreover, in another study conducted on soil of Jhangar Valley, Punjab province, the maximum total content of $\mathrm{Ni}$ was recorded as $81 \mathrm{mg} / \mathrm{Kg}$ (mean $31.93 \mathrm{mg} / \mathrm{kg}$ ); the author concluded that these values do not pose any potential health hazard to the general population [72]. In coastal sediments of the Arabian sea along with the urban Karachi, the maximum concentration of $74 \mathrm{mg} / \mathrm{kg} \mathrm{Ni}$ was found at the Lyari location at the most downstream part of the Malir River [81]. Similarly, in another study the second highest value of $56.46 \mathrm{mg} / \mathrm{kg}$ was found at Karachi Port Trust (KPT) Boat Building Area [80]. As per IARC, Ni compounds are human carcinogens by inhalation exposure; therefore, no safe level for nickel compounds can be recommended in air (assuming a linear dose-response) $[82,98]$. In the current analysis, the concentration of $\mathrm{Ni}$ in particulate matter was reported in the range of $0.001-0.15 \mu \mathrm{g} / \mathrm{m}^{3}$ and the highest of its content was reported in urban atmosphere of Islamabad [85]. In vegetables, the concentrations of $\mathrm{Ni}$ ranging from $<0.02$ to $67.8 \mathrm{mg} / \mathrm{kg}$ with mean value of $30.1 \mathrm{mg} / \mathrm{kg}$ was observed in vegetables irrigated with sewage water in the suburbs of Peshawar city, KPK [78]. The author reported the significant positive correlation of plant heavy metal with the given heavy metals in soil. In another research, the second highest mean Ni concentration of $28 \mathrm{mg} / \mathrm{kg}$ was observed in Spinach (Spinacia oleracea) irrigated by sewage water Hasan Abdal area, Punjab province [23].

2.5. Copper. Copper is an essential element and is always present in food and in animal liver, which are the major contributors to dietary exposure to copper $[129,130] . \mathrm{Cu}$ acts as a reductant in the enzymes superoxide dismutase, cytochrome oxidase, lysyl oxidase, dopamine hydroxylase, and several other oxidases that reduce molecular oxygen. It is transported in the organism by the protein ceruloplasmin [131]. The recommended dietary allowance (RDA) for adults is $0.9 \mathrm{mg} /$ day. The median dietary intake of copper in USA is approximately 1.0 to $1.6 \mathrm{mg} /$ day and the tolerable upper intake level for adults is $10 \mathrm{mg} /$ day [130]. In Pakistan, surface and ground water contamination with $\mathrm{Cu}$ does not pose any significant problems, as most of studies report the $\mathrm{Cu}$ concentration within acceptable WHO/NSDWQ-Pak standard limits of $2 \mathrm{mg} / \mathrm{L}$ (Table 1, Figures 3 and 4) [20]. There is only one study that shows the detectable dissolved concentration of $\mathrm{Cu}$ in ground water ranging from $<0.0001$ to $2.8 \mathrm{mg} / \mathrm{L}$ [8]. Municipal water (well water) from Pothi Bala of AJ\&K showed the highest concentration of $2.8 \mathrm{mg} / \mathrm{L} \mathrm{Cu}$, while in all other studies the concentration of $\mathrm{Cu}$ in drinking water was within the safe limits [8].

According to European Standards, the allowable concentration of $\mathrm{Cu}$ in soil (on which sewage sludge is applied) is $50-140 \mathrm{mg} / \mathrm{kg}(6<\mathrm{pH}<7)[64,132]$. In various regions of Pakistan, the $\mathrm{Cu}$ concentration in soil and dust ranges from $<6$ to $412 \mathrm{mg} / \mathrm{kg}$ (Table 2 ), where contaminated site from Kohistan region reported the highest content of 
$\mathrm{Cu}$ in soil [74]. The capital city of Pakistan (Islamabad) industrial area shows that the total concentration of $\mathrm{Cu}$ is in the range of $8.88-357.40 \mathrm{mg} / \mathrm{kg}$ [75]. The highest level of $\mathrm{Cu}$ in sediments was found at the Gizri Creek location at the most downstream part of the Malir River, Karachi, $272 \mathrm{mg} / \mathrm{kg}$ [80]. Similarly, Rauf et al. reported high level of $\mathrm{Cu}$ contents, that is, $159.79 \mathrm{mg} / \mathrm{kg}$, from sediments of River Ravi, Punjab [79]. Higher Cu concentration in soil can cause bioaccumulation in plants, especially the soil which is irrigated by the wastewater or on which sewage sludge is applied. A recent study from Lahore, Punjab province, reported the $\mathrm{Cu}$ contents in industrial wastewater irrigated vegetables, compared with the clean reference soil (spinach mean $5.77 \mathrm{mg} / \mathrm{kg}$ on contaminated soil and $0.44 \mathrm{mg} / \mathrm{kg}$ on clean soil, resp.). The authors concluded that the leafy vegetables have a higher ability to accumulate the heavy metals from soil compared with the other edible parts [63]. In Gillgit, Northern Pakistan, the concentrations of $\mathrm{Cu}$ ranged from 09 to $75 \mathrm{mg} / \mathrm{kg}$ in all the vegetable samples [73]. These values seem to be alarming keeping in view the tolerable upper intake level of $10 \mathrm{mg} \mathrm{Cu}$ /day [130].

2.6. Chromium. Chromium is an important element especially in metallurgical/steel or pigment industry. Both of its oxidation forms $(+3$ and +6$)$ in the chemical are used primarily in pigments, metal finishing, and wood preservatives [114]. The main source of $\mathrm{Cr}$ pollution is considered to be from dyestuffs and leather tanning when wastes are discharged directly into waste streams. Cr potentiates the action of insulin and may improve glucose tolerance and its $+3\left(\mathrm{Cr}^{3+}\right.$, or $\left.\mathrm{Cr}(\mathrm{III})\right)$ form is found in food, which is the most stable oxidation state and its compound occurs naturally [133]. The adequate intake (AI) was established for $\mathrm{Cr}$ (III) as 25-35 $\mu \mathrm{g} /$ day (female-male); few serious adverse effects have been associated with excess intake of $\mathrm{Cr}$ from food [133]. The toxic form of Cr occurs in +6 oxidation state $(\mathrm{Cr}(\mathrm{VI}))$, and its compounds cause cancer of the lung and positive associations have also been observed between exposure to $\mathrm{Cr}$ (VI) compounds and cancer of the nose and nasal sinuses [98]. IARC classified Cr(VI) compounds as Group 1 and they are carcinogenic to humans [98]. In ground water samples from various regions in Pakistan show $\mathrm{Cr}$ variation ranging from $<0.001$ to $9.8 \mathrm{mg} / \mathrm{L}$, being the highest (mean value $2.12 \mathrm{mg} / \mathrm{L}$ ) in well water from residential area, Kasur, Punjab province [27], whereas surface water contamination was found in the range of $0.16-0.29 \mathrm{mg} / \mathrm{L}$ Bara River, Nowshera, KPK province (Table 1) [53]. Both of these studies show industrial waste water impacts on water quality. The extent of harm caused by these elevated $\mathrm{Cr}$ concentrations in ground and surface water cannot be predicted precisely unless the $\mathrm{Cr}$ speciation $(\mathrm{Cr}(\mathrm{III})$ or $\mathrm{Cr}(\mathrm{VI}))$ is described properly. With a few exceptions $[74,75]$, most of studies report the Cr content in soil within the acceptable range of $100-150 \mathrm{mg} / \mathrm{kg}$ (Table 2), and the world soil average content of $\mathrm{Cr}$ has been established as $60 \mathrm{mg} / \mathrm{kg}$ [114]. A very high content of $\mathrm{Cr}$ in leaf and edible portion of vegetables, that is, 3.74 and $7.56 \mathrm{mg} / \mathrm{kg}$, has been reported [78]. In another study, significantly higher $3.93 \mathrm{mg} / \mathrm{kg} \mathrm{Cr}$ was reported in spinach irrigated with waste water containing higher $\mathrm{Cr}$ content, while irrigation with clean water results $0.004 \mathrm{mg} / \mathrm{kg}$ in same vegetable [23].

2.7. Iron. Iron is an important element in human body metabolism which acts as a catalyst and is present in greater amount than any other trace element. Iron $(\mathrm{Fe})$ functions as a component of a number of proteins, including enzymes and hemoglobin [130]. The RDA for both male and female is $8 \mathrm{mg}$ /day and the tolerable upper intake level for adults is $45 \mathrm{mg} /$ day of $\mathrm{Fe}$, which is based on gastrointestinal distress as an adverse effect [130]. There is no guideline value sets for $\mathrm{Fe}$ in drinking water by WHO, NSDWQ-Pak, or EU standards $[19,20,64]$. Almost all of the studies report the appreciable amount of Fe present in ground and surface water in Pakistan, which helps to keep the required RDA of the population (Table 1). Various studies reported iron concentrations in ground water ranging from $<0.01$ to $11.8 \mathrm{mg} / \mathrm{L}$ and highest concentration reported from Kasur city, Punjab [27], followed by $4.28 \mathrm{mg} / \mathrm{L}$ from Jamshoro, Sindh [41]. However, in surface water, the Fe content ranges from 0.01 to $5.46 \mathrm{mg} / \mathrm{L}$ in different localities of Pakistan [57]. The permissible value of iron in waste water according to NEQS is $8 \mathrm{mg} / \mathrm{L}$ [58]. The analysis of data for waste water in various cities of Pakistan revealed that the most areas have Fe content under the safe limits of $8 \mathrm{mg} / \mathrm{L}$ (Table 1 ) with a few exceptions [36].

Most of the reported studies (Table 2) from different regions of Pakistan reflect the anthropogenic pressure on soil in terms of heavy metal pollution through wastewater/sludge treatment or industrial activities. However, in case of Fe, this pressure buildup does not affect the plant growth as easily soluble and exchangeable fractions of $\mathrm{Fe}$ are very low in comparison with the total Fe content in soil [114]. Range of Fe content in soil from different regions is $<1$ to $196 \mathrm{mg} / \mathrm{kg}$ (Table 2). Moreover, exceptionally high value of 25080 to $26960 \mathrm{mg} / \mathrm{kg}$ (mean values) of Fe was reported in contaminated soil of Kohistan regions [74]. In current literature survey, the average Fe content in vegetables was found in the range from 7.28 to $500 \mathrm{mg} / \mathrm{kg}$, the highest of all cases found in spinach irrigated by sewage water [23].

2.8. Zinc. Zinc is essential micronutrient and catalyzes enzyme activity, contributes to protein structure, and regulates gene expression [130]. Although consequences of Zn deficiency have been recognized for many years but it can be toxic when exposures exceed physiological needs [134]. The adverse effects associated with chronic intake of supplemental $\mathrm{Zn}$ include acute gastrointestinal effects and headaches, impaired immune function, changes in lipoprotein and cholesterol levels, reduced copper status, and zinciron interactions [133]. The RDA of $\mathrm{Zn}$ for adults is 8$11 \mathrm{mg} /$ day (female-male), whereas the tolerable upper intake level is $40 \mathrm{mg} /$ day for adults, a value based on reduction in erythrocyte copper-zinc superoxide dismutase activity [130, 133].

For drinking water NSDWQ-Pak set maximum acceptable concentrations of $5 \mathrm{mg} / \mathrm{L}$ for $\mathrm{Zn} \mathrm{[19].} \mathrm{Both} \mathrm{in} \mathrm{ground}$ and in surface waters in Pakistan, the $\mathrm{Zn}$ level was found well below the standards set by NSDWQ-Pak (Table 1, Figures 3 and 4); however, on the other hand, this data shows the 
water deficiency in $\mathrm{Zn}$, which hinders this source to meet the RDA. Average zinc ( $\mathrm{Zn}$ ) content of the worldwide soils is estimated to be $70 \mathrm{mg} / \mathrm{kg}$ that is the same average level of $\mathrm{Zn}$ in the earth's crust [114]. The standard limit of $\mathrm{Zn}$ in soil (for sewage sludge applications) set by EU is $150-300 \mathrm{mg} / \mathrm{kg}$ [64]. In Pakistan the concentration of $\mathrm{Zn}$ in soil/dust varies from $>0.1$ to $1193 \mathrm{mg} / \mathrm{kg}$ (Table 2) with only exception where the highest concentration of $\mathrm{Zn}$ in soil/dust was observed in contaminated area, that is, $29755[64,74]$. However, in road side soil along National Highway (Hyderabad, Sindh province), the $\mathrm{Zn}$ varied from 13.8 to $180 \mathrm{mg} / \mathrm{kg}$ on dry weight basis [77]. As $\mathrm{Zn}$ is another significant element of automobile components, its presence in the roadside soil showed that vehicular traffic is the major anthropogenic source of pollution [77]. Soluble forms of $\mathrm{Zn}$ are readily available to plants, and the uptake of $\mathrm{Zn}$ has been reported to be linear with metal concentration in the nutrient solution and in soils, and $\mathrm{Zn}$ contents of plants vary considerably, reflecting the different factors of various ecosystems and of the genotypes [114]. Background $\mathrm{Zn}$ content in lettuce worldwide was found in the range of $44-73 \mathrm{mg} / \mathrm{kg}$ [114]. In Pakistan, the highest concentration of $\mathrm{Zn}$ of $271 \mathrm{mg} / \mathrm{kg}$ was found in B. campestris and $247 \mathrm{mg} / \mathrm{kg}$ in M. Sylvestris vegetables sampled from different parts of Gillgit, Pakistan [73].

\section{Health Impacts}

Heavy metals are of great concern because of their toxic properties and some heavy metals are also essential for the survival and health of humans. However, for these heavy metals (either essential or toxic) the health risk requirement requires consideration of toxicity from excessive exposure. In many parts of the country, heavy metal contamination has been reported as a serious problem but very few studies are available concerning its health effect on the local population. A study conducted by Arain et al. showed that 30-40\% people of the Bobak village (near Manchar Lake, Sindh) were suffering from rough skin with black dots and arsenical skin lesions, especially on face, arms, and feet, possibly due to overexposure of high arsenic contents; however, the other factors cannot be ignored [135]. The authors estimated the daily total As intake of $343.5 \mu \mathrm{g} /$ day for adults from foodstuffs in As affected area (irrigated with lake water), whereas As intake from lake and ground water was estimated in the range of 241-390 $\mu \mathrm{g}$ As/4L/day [135]. Another study revealed that 61 to $73 \%$ people of villages on the bank of Manchar Lake suffer from chronic arsenic toxicity like melanosis and keratosis [136]. The authors discovered a strong correlation between arsenic concentrations in drinking water and scalp hair and blood samples of exposed population. Moreover, the exposed people had clinical features like respiratory problems, anemia, gastrointestinal problems, muscles cramps, and weakness. As intake from lake and ground water was estimated in the range of 33.6-390 (males) $\mu \mathrm{g}$ As/4L/day [136]. Similarly, Baig et al. also reported significant correlation between As contents of drinking water and As concentration in scalp hair from subdistrict Gambit (Southern Sindh, Pakistan) [45]. In a comparative cross-sectional study, an association between chronic arsenic exposure through drinking groundwater and decrement in lung function among adult population was reported in Gambat, district Khairpur, Sindh province, in Pakistan [137]. In Pakistan, few studies have been carried out on the health effects of lead through multiple lead exposure sources, although excessively high lead levels in drinking water have been reported in many areas of country (Table 1). One community-based study hypothesized that high lead levels in blood may be a factor associated with hypertension in the Pakistani population [138]. In a study conducted by Rahbar et al., they found that $80 \%$ of children of Karachi had elevated blood lead concentrations $(>10 \mu \mathrm{g} / \mathrm{dL}$, with an overall mean of $15.6 \mu \mathrm{g} / \mathrm{dL}$ ) due to high level of lead in the air derived from petrol and contamination of food by street dust [139]. Similarly, the mean blood lead levels were found significantly higher in traffic constables from Karachi city $(47.7 \mu \mathrm{g} / \mathrm{dL})$ as compared to Islamabad city $(27.2 \mu \mathrm{g} / \mathrm{dL})$ than control $(3.22 \mu \mathrm{g} / \mathrm{dL})[140]$. As a consequence, neurological, physiological, and behavioral problems were also observed in exposed population having high level of lead in the blood $[139,140]$. Environmental Cd exposure in schoolchildren of the Lahore region has been reported recently [141]. In the same cross-sectional study, the Cd association was reported with bone resorption, suggesting a direct osteotoxic effect with increased calciuria [141].

\section{Conflict of Interests}

The authors declare that there is no conflict of interests regarding the publication of this paper.

\section{References}

[1] I. Pais and J. B. Jones, Eds., The Handbook of Trace Elements, CRC Press LLC, Boca Ratan, Fla, USA, 1997.

[2] M. Stoeppler, Ed., Hazardous Metals in the Environment, Elsevier Science Publishers B.V, Amsterdam, The Netherlands, 1992.

[3] A. Azizullah, M. N. K. Khattak, P. Richter, and D. Häder, "Water pollution in Pakistan and its impact on public health-a review," Environment International, vol. 37, no. 2, pp. 479-497, 2011.

[4] B. Wei and L. Yang, "A review of heavy metal contaminations in urban soils, urban road dusts and agricultural soils from China," Microchemical Journal, vol. 94, no. 2, pp. 99-107, 2010.

[5] K. E. Giller, E. Witter, and S. P. Mcgrath, "Toxicity of heavy metals to microorganisms and microbial processes in agricultural soils: a review," Soil Biology and Biochemistry, vol. 30, no. 10-11, pp. 1389-1414, 1998.

[6] WWF, "Pakistan's Waters at risk: Freshwater \& Toxics Programme," WWF-Pakistan, 2007.

[7] PCRWR, Water Quality Status in Rural Areas of Pakistan, Pakistan Council of Research in Water Resources, Islamabad, Pakistan, 2010.

[8] S. Javaid, S. G. S. Shah, A. J. Chaudhary, and M. H. Khan, "Assessment of trace metal contamination of drinking water in the Pearl Valley, Azad Jammu and Kashmir," Clean-Soil, Air, Water, vol. 36, no. 2, pp. 216-221, 2008.

[9] PCRWR, "Water quality status in Pakistan, 1st report 20012002," Pakistan Council of Research in Water Resources, 2002.

[10] Midrar-Ul-Haq, R. A. Khattak, H. K. Puno, M. S. Saif, and K. S. Memon, "Surface and ground water contamination in 
NWFP and Sindh provinces with respect to trace elements," International Journal of Agriculture and Biology, vol. 7, pp. 214217, 2005.

[11] M. Tariq, M. Ali, and Z. Shah, "Characteristics of industrial effluents and their possible impacts on quality of underground water," Soil \& Environment, vol. 25, pp. 64-69, 2006.

[12] J. J. McAlister, B. J. Smith, J. B. Neto, and J. K. Simpson, "Geochemical distribution and bioavailability of heavy metals and oxalate in street sediments from Rio de Janeiro, Brazil: a preliminary investigation," Environmental Geochemistry and Health, vol. 27, no. 5-6, pp. 429-441, 2005.

[13] S. M. Saifullah, S. H. Khan, and S. Ismail, "Distribution of nickel in a polluted mangrove habitat of the Indus Delta," Marine Pollution Bulletin, vol. 44, no. 6, pp. 570-576, 2002.

[14] F. Hasnie and N. Qureshi, "Quantification of pollution load in wastewater channels of village Rehri draining in to Korangi Creek," Pakistan Steel Research Journal, vol. 3, pp. 47-54, 2002.

[15] R. Qari, S. A. Siddiqui, and N. A. Qureshi, "A comparative study of heavy metal concentrations in surficial sediments from coastal areas of Karachi, Pakistan," Marine Pollution Bulletin, vol. 50, no. 5, pp. 595-599, 2005.

[16] N. U. Hassan, Q. Mahmood, A. Waseem, M. Irshad, and A. Pervez, "Assessment of heavy metals in wheat plants irrigated with contaminated wastewater," Polish Journal of Environmental Studies, vol. 22, no. 1, pp. 115-123, 2013.

[17] Z. Ullah, H. Khan, A. Waseem, Q. Mahmood, and U. Farooq, "Water quality assessment of the River Kabul at Peshawar, Pakistan: industrial and urban wastewater impacts," Journal of Water Chemistry and Technology, vol. 35, pp. 170-176, 2013.

[18] F. Stagnitti, J. Sherwood, G. Allinson et al., "An investigation of localised soil heterogeneities on solute transport using a multisegement percolation system," New Zealand Journal of Agricultural Research, vol. 41, no. 4, pp. 603-612, 1998.

[19] NSDWQ-Pak, "National Standards for Drinking Water Quality," Health Services Academy, Ministry of Health, Government of Pakistan, 2008.

[20] WHO, Guidelines for Drinking-Water Quality, World Health Organisation, 4th edition, 2011.

[21] M. Umar, A. Waseem, M. A. Sabir, A. M. Kassi, and A. S. Khan, "The Impact of Geology of Recharge Areas on Groundwater Quality: a case study of Zhob River Basin, Pakistan," CleanSoil, Air, Water, vol. 41, no. 2, pp. 119-127, 2013.

[22] A. Farooqi, N. Firdous, H. Masuda, and N. Haider, "Fluoride and arsenic poisoning in ground water of Kalalanwala area, near Lahore, Pakistan," Geochimica et Cosmochimica Acta, vol. 67, p. A90, 2003.

[23] M. I. Lone, S. Saleem, T. Mahmood, K. Saifullah, and G. Hussain, "Heavy metal contents of vegetables irrigated by sewage/tube-well water," International Journal of Agricultural Biology, vol. 5, pp. 533-535, 2003.

[24] A. Farooqi, H. Masuda, and N. Firdous, "Toxic fluoride and arsenic contaminated groundwater in the Lahore and Kasur districts, Punjab, Pakistan and possible contaminant sources," Environmental Pollution, vol. 145, no. 3, pp. 839-849, 2007.

[25] A. Farooqi, H. Masuda, M. Kusakabe, M. Naseem, and N. Firdous, "Distribution of highly arsenic and fluoride contaminated groundwater from east Punjab, Pakistan, and the controlling role of anthropogenic pollutants in the natural hydrological cycle," Geochemical Journal, vol. 41, no. 4, pp. 213-234, 2007.

[26] R. T. Nickson, J. M. McArthur, B. Shrestha, T. O. Kyaw-Myint, and D. Lowry, "Arsenic and other drinking water quality issues,
Muzaffargarh District, Pakistan," Applied Geochemistry, vol. 20, no. 1, pp. 55-68, 2005.

[27] S. R. Tariq, M. H. Shah, N. Shaheen, M. Jaffar, and A. Khalique, "Statistical source identification of metals in groundwater exposed to industrial contamination," Environmental Monitoring and Assessment, vol. 138, no. 1-3, pp. 159-165, 2008.

[28] I. A. Toor and S. N. A. Tahir, "Study of arsenic concentration levels in pakistani drinking water," Polish Journal of Environmental Studies, vol. 18, no. 5, pp. 907-912, 2009.

[29] M. A. Malana and M. A. Khosa, "Groundwater pollution with special focus on arsenic, Dera Ghazi Khan-Pakistan," Journal of Saudi Chemical Society, vol. 15, no. 1, pp. 39-47, 2011.

[30] R. Ullah, R. N. Malik, and A. Qadir, "Assessment of groundwater contamination in an industrial city, Sialkot, Pakistan," African Journal of Environmental Science and Technology, vol. 3, pp. 429-446, 2009.

[31] G. Akhter, Z. Ahmad, J. Iqbal, N. Shaheen, and M. H. Shah, "Physicochemical characterization of groundwater in urban areas of Lahore, Pakistan, with special reference to arsenic," Journal of the Chemical Society of Pakistan, vol. 32, no. 3, pp. 306-312, 2010.

[32] A. Taskeen, I. Naeem, and Z. Siddique, "Public health risk of Arsenic contamination in food at old Kahna, Lahore, Pakistan," Asian Journal of Chemistry, vol. 21, no. 4, pp. 2845-2848, 2009.

[33] A. Ilyas and T. Sarwar, "Study of trace elements in drinking water in the vicinity of Palosi drain, Peshawar," Pakistan Journal of Biological Sciences, vol. 6, pp. 86-91, 2003.

[34] R. A. Sial, M. F. Chaudhary, S. T. Abbas, M. I. Latif, and A. G. Khan, "Quality of effluents from Hattar Industrial Estate.," Journal of Zhejiang University. Science B, vol. 7, no. 12, pp. 974980, 2006.

[35] S. R. Tariq, M. H. Shah, N. Shaheen, A. Khalique, S. Manzoor, and M. Jaffar, "Multivariate analysis of trace metal levels in tannery effluents in relation to soil and water: a case study from Peshawar, Pakistan," Journal of Environmental Management, vol. 79, no. 1, pp. 20-29, 2006.

[36] S. Manzoor, M. H. Shah, N. Shaheen, A. Khalique, and M. Jaffar, "Multivariate analysis of trace metals in textile effluents in relation to soil and groundwater," Journal of Hazardous Materials, vol. 137, no. 1, pp. 31-37, 2006.

[37] M. Ishaq, F. A. Jan, M. A. Khan, I. Ihsanullah, I. Ahmad, and M. Shakirullah, "Effect of mercury and arsenic from industrial effluents on the drinking water and comparison of the water quality of polluted and non-polluted areas: a case study of Peshawar and Lower Dir," Environmental Monitoring and Assessment, vol. 185, no. 2, pp. 1483-1494, 2013.

[38] G. M. Arain, M. Aslam, S. A. Majidano, and M. Y. Khuhawar, "A preliminary study on the arsenic contamination of underground water of Matiari and Khairpur Districts, Sindh, Pakistan," Journal of the Chemical Society of Pakistan, vol. 29, no. 5, pp. 463-467, 2007.

[39] M. S. Saif, Midrar-Ul-Haq, and K. S. Memon, "Heavy metals contamination through industrial effluent to irrigation water and soil in Korangi area of Karachi (Pakistan)," International Journal of Agriculture and Biology, vol. 7, pp. 646-648, 2005.

[40] M. B. Arain, T. G. Kazi, J. A. Baig et al., "Respiratory effects in people exposed to arsenic via the drinking water and tobacco smoking in southern part of Pakistan," The Science of the Total Environment, vol. 407, no. 21, pp. 5524-5530, 2009.

[41] J. A. Baig, T. G. Kazi, M. B. Arain et al., "Evaluation of arsenic and other physico-chemical parameters of surface and ground 
water of Jamshoro, Pakistan," Journal of Hazardous Materials, vol. 166, no. 2-3, pp. 662-669, 2009.

[42] S. A. Majidano and M. Y. Khuhawar, "Distribution of heavy metals in the ground water of Taluka Daur, District Nawabshah, Sindh, Pakistan, and its impacts on human health," Journal of the Chemical Society of Pakistan, vol. 31, no. 3, pp. 408-414, 2009.

[43] M. A. Arain, Z. Haque, N. Badar, and N. Mughal, "Drinking water contamination by chromium and lead in industrial lands of Karachi," Journal of the Pakistan Medical Association, vol. 59, no. 5, pp. 270-274, 2009.

[44] J. Ahmed Baig, T. Gul Kazi, A. Qadir Shah et al., "Speciation and evaluation of Arsenic in surface water and groundwater samples: a multivariate case study," Ecotoxicology and Environmental Safety, vol. 73, no. 5, pp. 914-923, 2010.

[45] J. A. Baig, T. G. Kazi, A. Q. Shah et al., "Evaluation of toxic risk assessment of arsenic in male subjects through drinking water in southern Sindh Pakistan," Biological Trace Element Research, vol. 143 , no. 2 , pp. 772-786, 2011.

[46] Z. Karim, "Risk assessment of dissolved trace metals in drinking water of Karachi, Pakistan," Bulletin of Environmental Contamination and Toxicology, vol. 86, no. 6, pp. 676-678, 2011.

[47] N. Ul-Haq, M. A. Arain, N. Badar, M. Rasheed, and Z. Haque, "Drinking water: a major source of lead exposure in Karachi, Pakistan," Eastern Mediterranean Health Journal, vol. 17, no. 11, pp. 882-886, 2011.

[48] J. A. Baig, T. G. Kazi, A. Q. Shah et al., "Arsenic speciation and other parameters of surface and ground water samples of Jamshoro, Pakistan," International Journal of Environmental Analytical Chemistry, vol. 92, no. 1, pp. 28-42, 2012.

[49] K. D. Brahman, T. G. Kazi, H. I. Afridi, S. Naseem, S. S. Arain, and N. Ullah, "Evaluation of high levels of fluoride, arsenic species and other physicochemical parameters in underground water of two sub districts of Tharparkar, Pakistan: a multivariate study," Water Research, vol. 47, no. 3, pp. 1005-1020, 2013.

[50] K. D. Brahman, T. G. Kazi, H. I. Afridi et al., "Simultaneously evaluate the toxic levels of fluoride and arsenic species in underground water of Tharparkar and possible contaminant sources: a multivariate study," Ecotoxicology and Environmental Safety, vol. 89, pp. 95-107, 2013.

[51] S. Muhammad, M. Tahir Shah, and S. Khan, "Arsenic health risk assessment in drinking water and source apportionment using multivariate statistical techniques in Kohistan region, northern Pakistan," Food and Chemical Toxicology, vol. 48, no. 10, pp. 2855-2864, 2010.

[52] S. Muhammad, M. T. Shah, and S. Khan, "Health risk assessment of heavy metals and their source apportionment in drinking water of Kohistan region, northern Pakistan," Microchemical Journal, vol. 98, no. 2, pp. 334-343, 2011.

[53] W. Nazif, S. Perveen, and S. A. Shah, "Evaluation of irrigation water for heavy metals of akbarpura area," Journal of Agricultral Biological Science, vol. 1, pp. 51-54, 2006.

[54] A. M. Yousafzal, A. R. Khan, and A. R. Shakoori, "Heavy metal pollution in River Kabul affecting the inhabitant fish population," Pakistan Journal of Zoology, vol. 40, no. 5, pp. 331339, 2008.

[55] M. H. S. Wattoo, F. H. Wattoo, S. A. Tirmizi, T. G. Kazi, M. I. Bhanger, and J. I. Qbal, "Pollution of phulali canal water in the city premises of Hyderabad: Metal monitoring," Journal of the Chemical Society of Pakistan, vol. 28, no. 2, pp. 136-143, 2006.
[56] G. M. Mastoi, S. G. S. Shah, and M. Y. Khuhawar, "Assessment of water quality of Manchar Lake in Sindh (Pakistan)," Environmental Monitoring and Assessment, vol. 141, no. 1-3, pp. 287-296, 2008.

[57] N. Raza, S. B. Niazi, M. Sajid, F. Iqbal, and M. Ali, "Studies on relationship between season and inorganic elements of Kallar Kahar Lake (Chakwal), Pakistan," Journal of Research (Science), Bahauddin Zakariya University, vol. 18, pp. 61-68, 2007.

[58] NEQS, National Environmental Quality Standards, S.R.O, 549 (I)/2000, Ministry of Environment, Local Government, and Rural Development, Islamabad, Pakistan, 2000.

[59] M. Akif, A. R. Khan, K. Sok, Z. Hussain, M. Khan, and A. Muhammad, "Textile effluents and their contribution towards aquatic pollution in the Kabul River (Pakistan)," Journal of the Chemical Society of Pakistan, vol. 24, no. 2, pp. 106-111, 2002.

[60] W. Rehman, A. Zeb, N. Noor, and M. Nawaz, "Heavy metal pollution assessment in various industries of Pakistan," Environmental Geology, vol. 55, no. 2, pp. 353-358, 2008.

[61] S. Khan, I. Ahmad, M. T. Shah, S. Rehman, and A. Khaliq, "Use of constructed wetland for the removal of heavy metals from industrial wastewater," Journal of Environmental Management, vol. 90, no. 11, pp. 3451-3457, 2009.

[62] S. R. Kashif, M. Akram, M. Yaseen, and S. Ali, "Studies on heavy metals status and their uptake by vegetables in adjoining areas of Hudiara drain in Lahore," Soil \& Environment, vol. 28, pp. 7-12, 2009.

[63] A. Mahmood and R. N. Malik, "Human health risk assessment of heavy metals via consumption of contaminated vegetables collected from different irrigation sources in Lahore, Pakistan," Arabian Journal of Chemistry, vol. 7, pp. 91-99, 2014.

[64] M. Radojevic and V. N. Bashkin, Practical Environmental Analysis, RSC Publishing, London, UK, 2006.

[65] S. Manzoor, M. H. Shah, N. Shaheen, S. R. Tariq, A. Khaliq, and M. Jaffar, "Distribution of heavy toxic metals in industrial effluents and relevant soils from selected oil and ghee industries in Hattar," Journal of the Chemical Society of Pakistan, vol. 26, no. 4, pp. 429-435, 2004.

[66] T. G. Kazi, M. K. Jamali, A. Siddiqui, G. H. Kazi, M. B. Arain, and H. I. Afridi, "An ultrasonic assisted extraction method to release heavy metals from untreated sewage sludge samples," Chemosphere, vol. 63, no. 3, pp. 411-420, 2006.

[67] R. Renner, "Exposure on tap: drinking water as an overlooked source of lead," Environmental Health Perspectives, vol. 118, no. 2, pp. A68-A74, 2010.

[68] Y. Faiz, M. Tufail, M. T. Javed, and M. M. Chaudhry, "Road dust pollution of $\mathrm{Cd}, \mathrm{Cu}, \mathrm{Ni}, \mathrm{Pb}$ and $\mathrm{Zn}$ along Islamabad Expressway, Pakistan," Microchemical Journal, vol. 92, no. 2, pp. 186-192, 2009.

[69] A. Farooqi, H. Masuda, R. Siddiqui, and M. Naseem, "Sources of arsenic and fluoride in highly contaminated soils causing groundwater contamination in Punjab, Pakistan," Archives of Environmental Contamination and Toxicology, vol. 56, no. 4, pp. 693-706, 2009.

[70] M. B. Arain, T. G. Kazi, J. A. Baig et al., "Determination of arsenic levels in lake water, sediment, and foodstuff from selected area of Sindh, Pakistan: estimation of daily dietary intake," Food and Chemical Toxicology, vol. 47, no. 1, pp. 242248, 2009.

[71] S. S. Ahmad and S. Erum, "Integrated assessment of heavy metals pollution along motorway M-2," Soil and Environment, vol. 29, no. 2, pp. 110-116, 2010. 
[72] H. M. Khan, Z. S. Chaudhry, M. Ismail, and K. Khan, "Assessment of radionuclides, trace metals and radionuclide transfer from soil to food of Jhangar Valley (Pakistan) using gamma-ray spectrometry," Water, Air, and Soil Pollution, vol. 213, no. 1-4, pp. 353-362, 2010.

[73] S. Khan, S. Rehman, A. Z. Khan, M. A. Khan, and M. T. Shah, "Soil and vegetables enrichment with heavy metals from geological sources in Gilgit, northern Pakistan," Ecotoxicology and Environmental Safety, vol. 73, no. 7, pp. 1820-1827, 2010.

[74] S. Muhammad, M. T. Shah, and S. Khan, "Heavy metal concentrations in soil and wild plants growing around $\mathrm{Pb}$ Zn sulfide terrain in the Kohistan region, northern Pakistan," Microchemical Journal, vol. 99, no. 1, pp. 67-75, 2011.

[75] R. N. Malik, S. Z. Husain, and I. Nazir, "Heavy metal contamination and accumulation in soil and wild plant species from industrial area of Islamabad, Pakistan," Pakistan Journal of Botany, vol. 42, no. 1, pp. 291-301, 2010.

[76] Z. I. Khan, M. Ashraf, K. Ahmad, and N. A. Akram, "A study on the transfer of cadmium from soil to pasture under semiarid conditions in Sargodha, Pakistan," Biological Trace Element Research, vol. 142, no. 2, pp. 143-147, 2011.

[77] M. N. Khan, A. A. Wasim, A. Sarwar, and M. F. Rasheed, "Assessment of heavy metal toxicants in the roadside soil along the N-5, National Highway, Pakistan," Environmental Monitoring and Assessment, vol. 182, no. 1-4, pp. 587-595, 2011.

[78] S. Perveen, A. Samad, W. Nazif, and S. Shah, "Impact of sewage water on vegetables quality with respect to heavy metals in Peshawar, Pakistan," Pakistan Journal of Botany, vol. 44, no. 6, pp. 1923-1931, 2012.

[79] A. Rauf, M. Javed, M. Ubaidullah, and S. Abdullah, "Assessment of heavy metals in sediments of the river Ravi, Pakistan," International Journal of Agriculture and Biology, vol. 11, no. 2, pp. 197-200, 2009.

[80] A. Siddique, M. Mumtaz, N. A. Zaigham et al., "Heavy metal toxicity levels in the coastal sediments of the Arabian Sea along the urban Karachi (Pakistan) region," Marine Pollution Bulletin, vol. 58, no. 9, pp. 1406-1414, 2009.

[81] A. Mashiatullah, M. Z. Chaudhary, N. Ahmad, T. Javed, and A. Ghaffar, "Metal pollution and ecological risk assessment in marine sediments of Karachi Coast, Pakistan," Environmental Monitoring and Assessment, vol. 185, no. 2, pp. 1555-1565, 2013.

[82] WHO, WHO Air Quality Guidelines for Europe, WHO, 2000.

[83] M. H. Shah, N. Shaheen, M. Jaffar, and M. Saqib, "Distribution of lead in relation to size of airborne particulate matter in Islamabad, Pakistan," Journal of Environmental Management, vol. 70, no. 2, pp. 95-100, 2004.

[84] M. H. Shah, N. Shaheen, M. Jaffar, A. Khalique, S. R. Tariq, and S. Manzoor, "Spatial variations in selected metal contents and particle size distribution in an urban and rural atmosphere of Islamabad, Pakistan," Journal of Environmental Management, vol. 78, no. 2, pp. 128-137, 2006.

[85] M. H. Shah and N. Shaheen, "Statistical analysis of atmospheric trace metals and particulate fractions in Islamabad, Pakistan," Journal of Hazardous Materials, vol. 147, no. 3, pp. 759-767, 2007.

[86] M. H. Shah and N. Shaheen, "Annual TSP and trace metal distribution in the urban atmosphere of Islamabad in comparison with mega-cities of the world," Human and Ecological Risk Assessment, vol. 13, no. 4, pp. 884-899, 2007.

[87] T. Shigeta, Environmental Investigation in Pakistan, PakEPA/JICA, Islamabad, Pakistan, 2000.
[88] M. H. Shah and N. Shaheen, "Annual and seasonal variations of trace metals in atmospheric suspended particulate matter in Islamabad, Pakistan," Water, Air, and Soil Pollution, vol. 190, no. 1-4, pp. 13-25, 2008.

[89] E. von Schneidemesser, E. A. Stone, T. A. Quraishi, M. M. Shafer, and J. J. Schauer, "Toxic metals in the atmosphere in Lahore, Pakistan," Science of the Total Environment, vol. 408, no. 7, pp. 1640-1648, 2010.

[90] EU, "Commission regulation (EC) No. 1881/2006, Setting maximum levels for certain contaminants in foodstuffs," Official Journal of the European Union, vol. 364, pp. 5-24, 2006.

[91] M. A. Khan, I. Ahmad, and I. Ur Rahman, "Effect of environmental pollution on heavy metals content of Withania somnifera," Journal of the Chinese Chemical Society, vol. 54, no. 2, pp. 339-343, 2007.

[92] M. Farooq, F. Anwar, and U. Rashid, "Appraisal of heavy metal contents in different vegetables grown in the vicinity of an industrial area," Pakistan Journal of Botany, vol. 40, no. 5, pp. 2099-2106, 2008.

[93] M. Abbas, Z. Parveen, M. Iqbal et al., "Monitoring of toxic metals (cadmium, lead, arsenic and mercury) in vegetables of Sindh, Pakistan," Kathmandu University Journal of Science, Engineering and Technology, vol. 6, pp. 60-65, 2010.

[94] J. A. Baig and T. G. Kazi, "Translocation of arsenic contents in vegetables from growing media of contaminated areas," Ecotoxicology and Environmental Safety, vol. 75, no. 1, pp. 2732, 2012.

[95] A. K. K. Achakzai, Z. A. Bazai, and S. A. Kayani, "Accumulation of heavy metals by lettuce (Lactuca sativa 1.) irrigated with different levels of wastewater of Quetta city," Pakistan Journal of Botany, vol. 43, pp. 2953-2960, 2011.

[96] A. U. Din, M. A. Abdel-Reheem, H. Ullah et al., "Assessment of heavy metals in onion and potato in imported and local variety of Pakistan and Afghanistan," Life Science Journal, vol. 10, pp. 198-204, 2013.

[97] I. H. Bukhari, M. Shoaib, M. J. Sarwar, S. Hafeez, T. H. Bokhari, and S. A. R. Naqvi, "Quantification and comparison of some heavy metals in scalp hair, finger nails and plasma of diabetic patients of sargodha zone (Pakistan)," Journal of the Chemical Society of Pakistan, vol. 34, no. 4, pp. 877-880, 2012.

[98] IARC, A Review of Human Carcinogens: Metals, Arsenic, Fibres and Dusts, vol. 100C, International Agency for Research on Cancer: Monographs on the Evaluation of Carcinogenic Risks to Humans, 2012.

[99] M. Çöl, C. Çöl, A. Soran, B. S. Sayli, and S. Öztürk, "Arsenicrelated Bowen's disease, palmar keratosis, and skin cancer," Environmental Health Perspectives, vol. 107, no. 8, pp. 687-689, 1999.

[100] K. H. Morales, L. Ryan, T.-L. Kuo, M.-M. Wu, and C.-J. Chen, "Risk of internal cancers from arsenic in drinking water," Environmental Health Perspectives, vol. 108, no. 7, pp. 655-661, 2000.

[101] P. L. Smedley and D. G. Kinniburgh, "A review of the source, behaviour and distribution of arsenic in natural waters," Applied Geochemistry, vol. 17, no. 5, pp. 517-568, 2002.

[102] M. M. Rahman, G. Owens, and R. Naidu, "Arsenic levels in rice grain and assessment of daily dietary intake of arsenic from rice in arsenic-contaminated regions of Bangladesh-implications to groundwater irrigation," Environmental Geochemistry and Health, vol. 31, no. 1, pp. 179-187, 2009.

[103] T. Roychowdhury, T. Uchino, H. Tokunaga, and M. Ando, "Survey of arsenic in food composites from an arsenic-affected 
area of West Bengal, India," Food and Chemical Toxicology, vol. 40, no. 11, pp. 1611-1621, 2002.

[104] D. Sarkar and R. Datta, "Arsenic fate and bioavailability in two soils contaminated with sodium arsenate pesticide: an incubation study," Bulletin of Environmental Contamination and Toxicology, vol. 72, no. 2, pp. 240-247, 2004.

[105] T. Ahmad, M. Kahlown, A. Tahir, and H. Rashid, "Arsenic an emerging issue: experiences from Pakistan," in Proceedings of the 30th WEDC International Conference, pp. 459-466, Vientiane, Lao PDR, 2004.

[106] A. N. S. Saqib, A. Waseem, A. F. Khan et al., "Arsenic bioremediation by low cost materials derived from Blue Pine (Pinus wallichiana) and Walnut (Juglans regia)," Ecological Engineering, vol. 51, pp. 88-94, 2013.

[107] NAPAM-2007-2011, National Action Plan for Arsenic Mitigation, Pakistan Water and Sanitation Gateway, Ministry of Environment, Government of Pakistan.

[108] B. Shrestha, "Drinking water quality: future directions for UNICEF in Pakistan," Consultancy Report 2 of 3, Water Quality, SWEET Project, UNICEF, Islamabad, Pakistan, 2002.

[109] S. L. Simpson, G. E. Batley, A. A. Chariton et al., Handbook for Sediment Quality Assessment, Centre for Environmental Contaminants Research, 2005.

[110] USEPA, "Sediment toxicity and fate of synthetic pyrethroids," Science Advisory Panel Final Report, US Environmental Protection Agency, Washington, DC, USA, 1999.

[111] D. Chakraborti, D. Das, A. Chatterjee, Z. Jin, and S. G. Jiang, "Direct determination of some heavy metals in urban air particulates by electrothermal atomic absorption spectrometry using Zeeman background correction after simple acid decomposition. Part IV: application to Calcutta air particulates," Environmental Technology, vol. 13, no. 1, pp. 95-100, 1992.

[112] J. M. Waldman, P. J. Lioy, M. Zelenka et al., "Wintertime measurements of aerosol acidity and trace elements in Wuhan, a city in central China," Atmospheric Environment B Urban Atmosphere, vol. 25, no. 1, pp. 113-120, 1991.

[113] F. N. Robertson, "Arsenic in ground-water under oxidizing conditions, South-west United States," Environmental Geochemistry and Health, vol. 11, no. 3-4, pp. 171-185, 1989.

[114] A. Kabata-Pendias, Trace Elements in Soils and Plants, CRC Press, New York, NY, USA, 2011.

[115] M. J. Abedin, M. S. Cresser, A. A. Meharg, J. Feldmann, and J. Cotter-Howells, "Arsenic accumulation and metabolism in rice (Oryza sativa L.)," Environmental Science and Technology, vol. 36, no. 5, pp. 962-968, 2002.

[116] M. F. Hossain, "Arsenic contamination in Bangladesh-an overview," Agriculture, Ecosystems and Environment, vol. 113, no. 1-4, pp. 1-16, 2006.

[117] R. W. Dabeka, A. D. McKenzie, G. M. Lacroix et al., "Survey of arsenic in total diet food composites and estimation of the dietary intake of arsenic by Canadian adults and children," Journal of AOAC International, vol. 76, no. 1, pp. 14-25, 1993.

[118] J. Godt, F. Scheidig, C. Grosse-Siestrup et al., "The toxicity of cadmium and resulting hazards for human health," Journal of Occupational Medicine and Toxicology, vol. 1, article 22, 2006.

[119] G. Nordberg, T. Jin, A. Bernard et al., "Low bone density and renal dysfunction following environmental cadmium exposure in China," A Journal of the Human Environment, vol. 31, no. 6, pp. 478-481, 2002.

[120] O. A. Al-Khashman, "The investigation of metal concentrations in street dust samples in Aqaba city, Jordan," Environmental Geochemistry and Health, vol. 29, no. 3, pp. 197-207, 2007.
[121] N. Sezgin, H. K. Ozcan, G. Demir, S. Nemlioglu, and C. Bayat, "Determination of heavy metal concentrations in street dusts in Istanbul E-5 highway," Environment International, vol. 29, no. 7, pp. 979-985, 2004.

[122] K. Cambra, T. Martínez, A. Urzelai, and E. Alonso, "Risk analysis of a farm area near a lead- and cadmium-contaminated industrial site," Soil and Sediment Contamination, vol. 8, no. 5, pp. 527-540, 1999.

[123] N. Amin, A. Hussain, S. Alamzeb, and S. Begum, "Accumulation of heavy metals in edible parts of vegetables irrigated with waste water and their daily intake to adults and children, District Mardan, Pakistan," Food Chemistry, vol. 136, no. 3-4, pp. 15151523, 2013.

[124] D. Loomis, Y. Grosse, B. Lauby-Secretan et al., "The carcinogenicity of outdoor air pollution," The Lancet Oncology, vol. 14, pp. 1262-1263, 2013.

[125] N. C. Papanikolaou, E. G. Hatzidaki, S. Belivanis, G. N. Tzanakakis, and A. M. Tsatsakis, "Lead toxicity update: a brief review," Medical Science Monitor, vol. 11, no. 10, pp. RA329RA336, 2005.

[126] IARC, IARC Monographs on the Evaluation of Carcinogenic Risks to Human, vol. 87, Inorganic and Organic Lead Compounds, International Agency for Research on Cancer, 2006.

[127] D. Hjortenkrans, B. Bergbäck, and A. Häggerud, "New metal emission patterns in road traffic environments," Environmental Monitoring and Assessment, vol. 117, no. 1-3, pp. 85-98, 2006.

[128] ATSDR, Toxicological Profile for Nickel, Agency for Toxic Substances and Disease Registry, US Public Health Service, 2005.

[129] R. Uauy, M. Olivares, and M. Gonzalez, "Essentiality of copper in humans," The American Journal of Clinical Nutrition, vol. 67, no. 5, pp. 952S-959S, 1998.

[130] DRI, Dietary Reference Intakes for Vitamin A, Vitamin K, Arsenic, Boron, Chromium, Copper, Iodine, Iron, Manganese, Molybdenum, Nickel, Silicon, Vanadium, and Zinc, The National Academies Press, 2001.

[131] B. R. Stern, "Essentiality and toxicity in copper health risk assessment: overview, update and regulatory considerations," Journal of Toxicology and Environmental Health A, vol. 73, no. 2-3, pp. 114-127, 2010.

[132] EU, "Working Document on sludge," 3rd Draft, European Union, Brussel, Belgium.

[133] DRI, Dietary Reference Intakes: The Essential Guide to Nutrient Requirements, The National Academies Press, 2006.

[134] N. W. Solomons and M. Ruz, "Trace element requirements in humans: an update," The Journal of Trace Elements in Experimental Medicine, vol. 11, pp. 177-195, 1998.

[135] M. B. Arain, T. G. Kazi, J. A. Baig et al., "Determination of arsenic levels in lake water, sediment, and foodstuff from selected area of Sindh, Pakistan: Estimation of daily dietary intake," Food and Chemical Toxicology, vol. 47, no. 1, pp. 242248, 2009.

[136] T. G. Kazi, M. B. Arain, J. A. Baig et al., "The correlation of arsenic levels in drinking water with the biological samples of skin disorders," Science of the Total Environment, vol. 407, no. 3, pp. 1019-1026, 2009.

[137] A. A. Nafees, A. Kazi, Z. Fatmi, M. Irfan, A. Ali, and F. Kayama, "Lung function decrement with arsenic exposure to drinking groundwater along River Indus," Environmental Geochemistry and Health, vol. 33, no. 2, pp. 203-216, 2011.

[138] S. Rahman, N. Khalid, J. H. Zaidi, S. Ahmad, and M. Z. Iqbal, "Non-occupational lead exposure and hypertension in 
Pakistani adults," Journal of Zhejiang University Science B, vol. 7, no. 9, pp. 732-737, 2006.

[139] M. H. Rahbar, F. White, M. Agboatwalla, S. Hozhabri, and S. Luby, "Factors associated with elevated blood lead concentrations in children in Karachi, Pakistan," Bulletin of the World Health Organization, vol. 80, no. 10, pp. 769-775, 2002.

[140] F. Agha, A. Sadaruddin, and N. Khatoon, "Effect of environmental lead pollution on blood lead levels in traffic police constables in Islamabad, Pakistan," Journal of the Pakistan Medical Association, vol. 55, no. 10, pp. 410-413, 2005.

[141] M. Sughis, J. Penders, V. Haufroid, B. Nemery, and T. S. Nawrot, "Bone resorption and environmental exposure to cadmium in children: a cross-sectional study," Environmental Health, vol. 10, no. 1, article 104, 2011. 

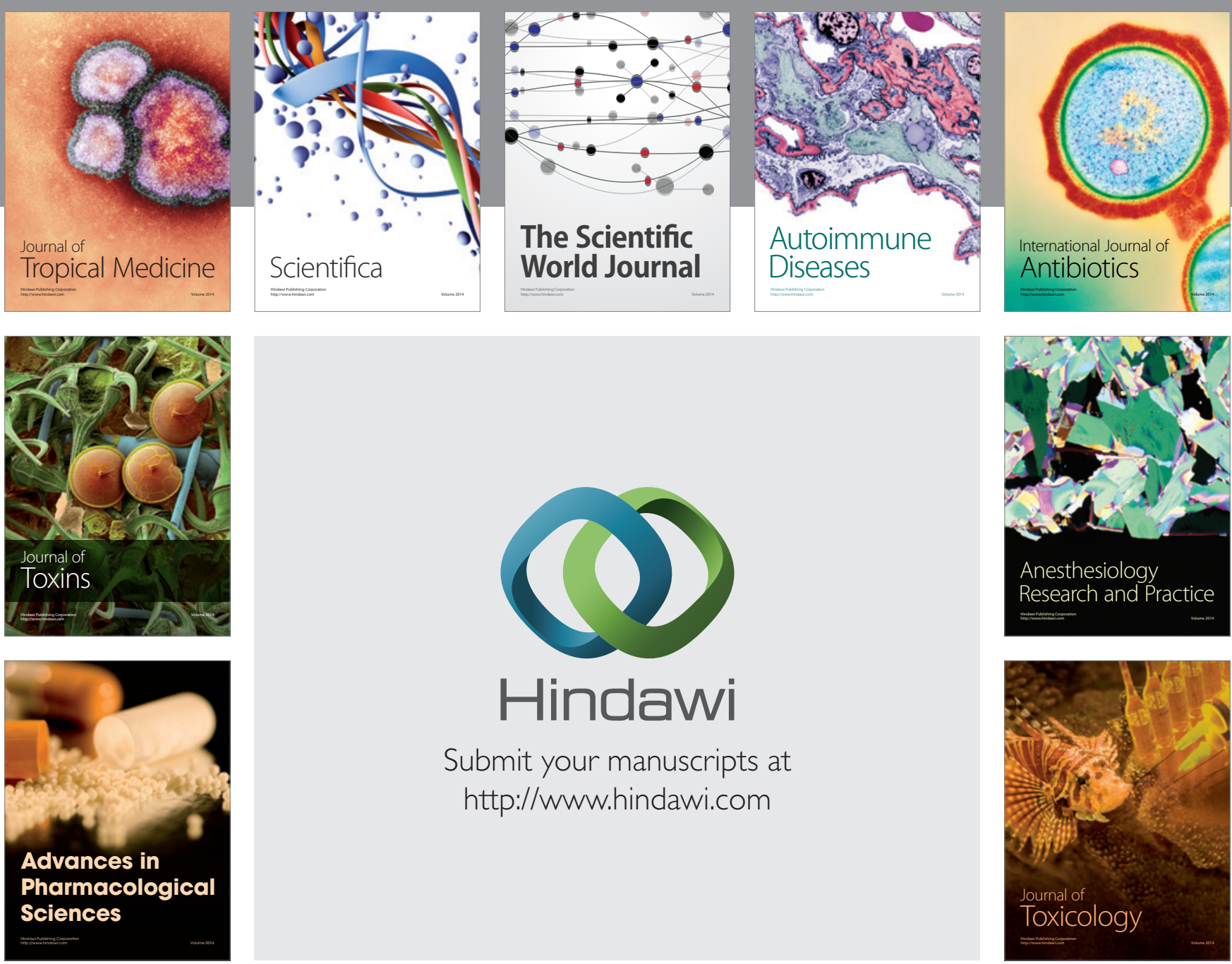

\section{Hindawi}

Submit your manuscripts at

http://www.hindawi.com
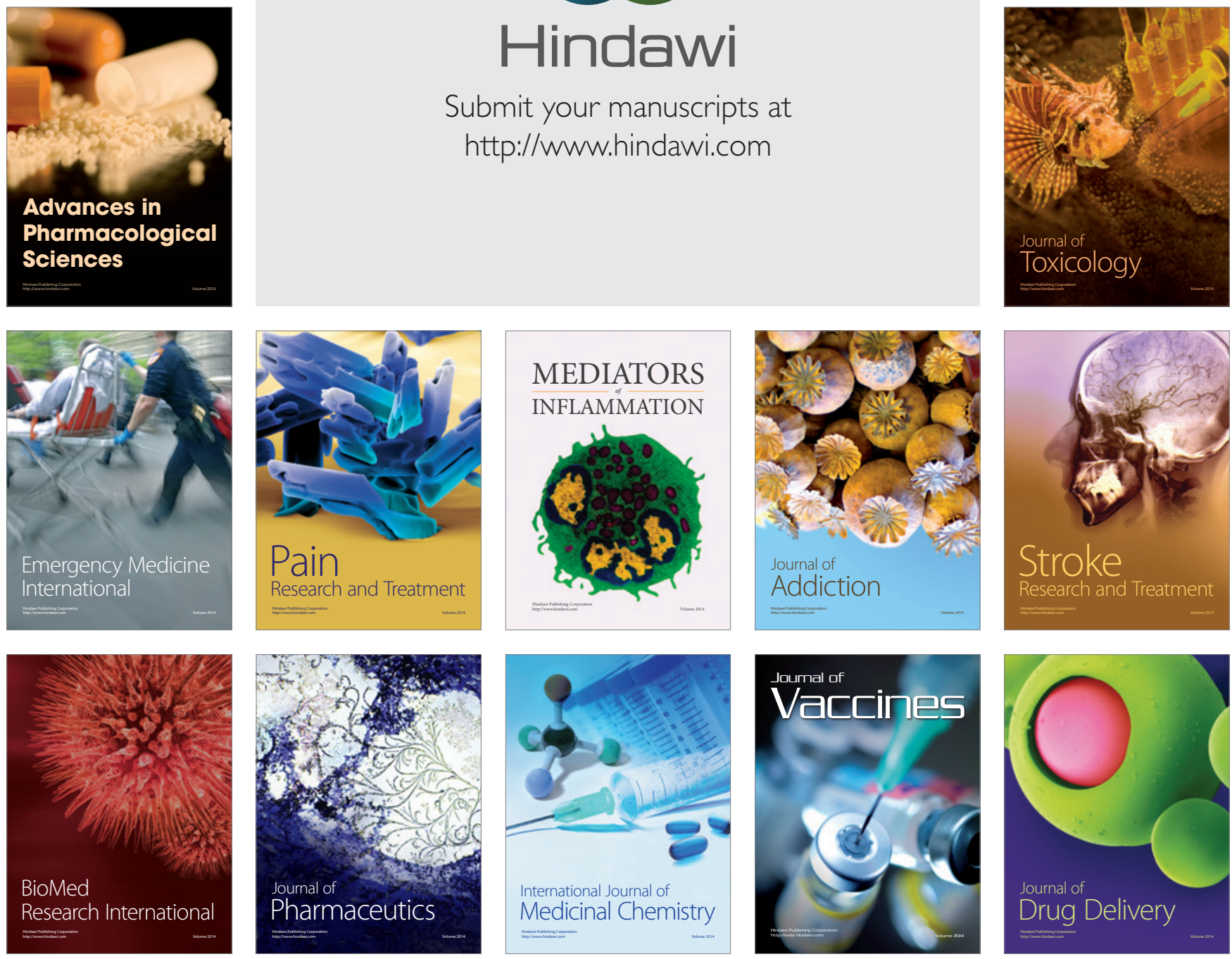